\title{
The Employment, Earnings, and Income of Less Skilled Workers
}

Over the Business Cycle

\author{
Hilary Hoynes \\ Department of Economics \\ 549 Evans Hall \\ University of California, Berkeley \\ Berkeley, CA 94720-3880 \\ hilary@econ.berkeley.edu
}

April, 1999

Prepared for the Conference on "Labor Markets and Less Skilled Workers," November 5-6, 1998, in Washington DC, sponsored by the Joint Center for Poverty Research. Warren Hrung and Darren Lubotsky provided excellent research assistance. I would like to thank Joe Altonji, Tim Bartik, Becky Blank, and Robert Moffitt for comments and David Card for many helpful discussions. Financial support comes from the NICHD and the Sloan Foundation. Computing support was provided by the Econometrics Laboratory at U.C. Berkeley. 


\begin{abstract}
In this paper, I examine the effect of business cycles on the employment, earnings, and income of persons in different demographic groups. I classify individuals by sex, education, and race. The analysis uses data from the Current Population Survey's Outgoing Rotation Group file, covering the period 1979-1992, and March Annual Demographic files (ADF) covering the period 1975-1997. Many different individual and family outcome measures are considered including: employment to population ratios, weekly earnings, hourly earnings, annual hours, annual earnings, family earnings, family transfer income, and total family income. The regression model is specified such that the key parameters measure how the labor market outcomes of less skilled workers vary with the business cycle relative to the variability for high skill groups. The analysis uses variation across MSAs in the timing and severity of shocks. The results consistently show that individuals with lower education levels, nonwhites, and low skill women experience greater cyclical fluctuation than high skill men. These results are the most striking when examining comprehensive measures of labor force activity such as the likelihood of full-time year around work. Government transfers and the earnings of other family members decrease the differences between groups, as business cycles have more skill-group neutral effects on family income than individual earnings. The paper examines the stability of these results by comparing evidence across the 1982 and 1992 recessions. The evidence suggests that the 1992 recession led to more uniform effects across skill groups than earlier cycles.
\end{abstract}




\section{Introduction}

One of the most substantial risks facing workers is the potential for job loss, either permanent or temporary. The possibility of a loss in earnings and employment is likely to be of greater concern to less skilled workers because of difficulties in replacing lost income with savings and the earnings of secondary earners. Many government transfer programs have been established to reduce the variability of family income over the business cycle. Because of recent changes in welfare programs, however, there is some uncertainty as to the role that the safety net can and will play in subsequent recessions.

Recent evidence suggests that state and federal policy changes are leading to increases in employment among AFDC recipients (Blank, Card and Robins, this volume). With increases in labor market attachment comes the potential for increases in family income and earnings. However, with increasing labor market attachment, also comes the risk of recession and loss of family income. The potential for cyclical fluctuation in earnings is very different than the relatively constant transfer that a family expected from AFDC.

This paper examines the impact of changes in local economic conditions on the employment, earnings and income of individuals in different skill groups. The skill groups are defined by sex, race, and education level. The emphasis in the paper is evaluating the relative impact of cycles across these demographic groups. This is done in three parts. First, I present trends in labor market outcomes by skill group. This simple analysis provides suggestive evidence that the employment and earnings patterns of less skilled groups show greater fluctuation in economic cycles than higher skill groups. Second, I examine how changes in labor market outcomes vary across skill groups within metropolitan statistical areas (MSAs). In particular, I present figures which compare the changes in a particular labor market outcome over a particular time period (e.g. from peak to trough of a recession) for one skill group against another within an MSA. Last, I extend the graphical analysis to a regression framework thereby estimating quantitatively the impact of a shock to an MSA on the relative outcomes across skill groups. 
The analysis uses data from the Current Population Survey's (CPS) Outgoing Rotation Group (ORG) data, covering the period 1979-1992, and March Annual Demographic files (ADF) covering the period 1975-1997. The advantage of the ORG data is that the samples are about three times as large as the ADF, which is particularly important when presenting results by skill groups within MSAs. The labor market outcomes that can be identified in the ORG data, however, are somewhat limited and include employment status last week and earnings last week. Ultimately, broader measures of individual and family well-being are important. The ADF provides comprehensive data on employment, earnings, and income over the past year. The analysis of the ADF data uses hourly earnings, annual hours, annual earnings, family earnings, family transfer income, and total family income. By combining evidence from the two data sources, the results tell a comprehensive story about the impact of business cycles on workers and families. The data also cover a relatively long time period, allowing for examination of the recessions over three decades.

The results consistently show that the labor market outcomes of less skilled workers exhibit more variability over business cycles than higher skill groups. Nonwhites, and those with lower education levels are more impacted by changes in local economic conditions. Further, high skilled women have significantly less sensitivity to business cycles than low skilled, especially low skilled nonwhite, women. These patterns hold for both recessions and recoveries. These groups are more likely to have reductions in employment and earnings during a downturn, and also more likely to have gains in recoveries. Examining individuals in isolation, however, gives an incomplete picture of the effect of cycles on wellbeing. The results also show that government transfers and the earnings of other family members decrease the differences between groups resulting in more skill-group neutral effects of business cycles on family income than individual earnings.

Many previous studies have examined the effects of business cycles and local labor markets on individuals and families. This paper contributes to the literature in three ways. First, the focus in this 
paper is on comparing the responses across groups defined by sex, education and race. This provides a comprehensive distributional analysis that has not been done in the existing literature. Second, the paper presents an empirical framework and applies it to an extensive set of individual and family outcomes. Previous studies typically focus on a relatively narrow set of outcomes. Third, the framework is used to examine whether the effects vary different business cycles.

The study is inherently a descriptive one, and does not make any attempt to causally identify why there is variation across skill groups in the relative responsiveness to cycles. Among the reasons that groups may have different responses to cycles are that they have different mobility rates, labor supply elasticities, and they work in different industries and occupations. There are two ways that I explore why the differences occur. First, we can examine the "channels" by which the differences occur by looking at wages, hours, and earnings separately and by examining the components of family income. Second, I compare the characteristics of workers in different skill groups to see if groups with higher cyclical responses are more likely to be employed in occupations and industries with higher layoff rates.

The remainder of the paper is as follows. Section 2 provides a summary of the existing literature on the impact of local labor markets on employment, earnings, and income. Section 3 describes the data. Section 4 presents the trends in individual and family outcomes over time by skill group. Section 5 describes the empirical approach. Section 6 provides a preliminary graphical analysis of differences in responsiveness to cycles across skill groups. The main regression results are presented in section 7. Section 8 concludes.

\section{Previous Literature}

This study has connections to many different areas of research including the literature on wage, earnings, and income inequality; trends in employment and earnings for women; determinants of labor market outcomes and differences between groups; and worker displacement. It is not feasible, nor 
desirable to provide a comprehensive review of the literature here. Instead, this review will focus explicitly on those studies that examine the effect of local labor market conditions (or other measures of business cycles) on employment and income.

The applications that are the most relevant to this analysis include those that examine the effect of business cycles and local labor markets on employment outcomes (Bartik 1991, 1993a, 1993b, and 1996, Blanchard and Katz 1992, Holzer 1991), real wages (Bils 1985, Blank 1990, Keane et al 1988, Solon et al 1994), racial differences in labor market outcomes (Bound and Holzer 1993 and 1995), labor market outcomes of disadvantaged youths (Acs and Wissoker 1991, Bound and Freeman 1992, Cain and Finnie 1990, Freeman 1982, 1991a, 1991b), and family income, poverty and income inequality (Bartik 1994, Blank 1989, Blank 1993, Blank and Blinder 1986, Blank and Card 1993, Cutler and Katz 1991). These studies almost universally find an important role for local labor market conditions.

For the purposes of this analysis, I will focus three features of these studies. The first is the variables used to control for the characteristics of the area labor market. The second is the outcome measures. The third is the degree to which differences across groups is explored.

The studies of disadvantaged youths relate labor market outcomes to local (typically Metropolitan Statistical Area or MSA) unemployment rates. That literature has consistently found that higher local unemployment rates lead to reductions in employment and earnings (Acs and Wissoker 1991, Bound and Freeman 1992, Cain and Finnie 1990, Freeman 1982, 1991a, 1991b), with larger effects for blacks, younger workers, and less educated workers (Acs and Wissoker 1991, and Freeman 1991b). The studies of family income and poverty have typically used either national (Blank 1989, Blank 1993, and Blinder 1986, Cutler and Katz 1991) or regional (Blank and Card 1993) variation in unemployment rates or GNP. The studies have found a consistent negative relationship between unemployment rates and inequality and poverty. Of particular interest is Blank (1989) who disaggregates household income into many components and examines the relative cyclicality of the components. She 
finds earnings and capital income to be pro-cyclical and some transfer income to be counter-cyclical. Overall, she finds greater variation over the cycle for those that are young, male, and nonwhite.

The literature that is most relevant for this study is the literature that uses variation across MSAs in labor market conditions to examine labor market outcomes across different demographic groups (Bartik 1991, 1993a, 1993b, 1994 and 1996, and Bound and Holzer 1993 and 1995). The studies by Bartik use growth in employment, changes in the manufacturing share of employment, and changes in the average wage premium implied by the area's industry mix. Bound and Holzer $(1993,1995)$ use skill group specific measures of employment growth, using as weights the skill group's participation in each industry at the beginning of the period. The results differ somewhat across the studies, but they generally show that changes in labor demand lead to larger changes for blacks, younger persons, and those with lower education levels. The patterns seem to hold for men and women

Distinct from the literature on labor market outcomes, above, is the literature that uses panel data to examine the cyclicality of real wages. The literature uses primarily aggregate measures of business cycles (national unemployment rates of GNP growth) and asks the question to what degree are aggregate wage fluctuations over the cycle due to changes in the composition of the work force. The results vary somewhat across the studies but generally find that the composition effect alone leads to counter cyclical wage patterns. Accounting for this composition effect, wages are found to be pro-cyclical with greater fluctuations for those who are male, young, and working in private sector.

Overall, these studies raise several possible explanations for the differences across groups in the sensitivity to business cycles. An often cited explanation is variation across demographic groups in mobility rates. The larger the long run supply elasticity for the demographic group, the lower the expected effect of a demand shift on wages and employment. Those with slower rates of population mobility will have larger effects. A second explanation is that different demographic groups tend to be employed in difference sectors and occupations that may be associated with greater or lesser risks of 
layoff.

\section{Data}

The study uses the Outgoing Rotation Group (ORG) and March Annual Demographic File (ADF) data from the Current Population Survey (CPS). The CPS Outgoing Rotation Group (ORG) data, which pools monthly survey observations, has sample sizes about three times as large as the ADF, but the labor market outcomes included in the survey are limited. I use indicators for employment last week, full-time employment last week, and earnings last week, where full-time includes those working at least 35 hours per week. The data covers $1979-1993$ with about 325,000 observations per year. ${ }^{1}$

The ADF (or March CPS) is an annual demographic file that includes labor market and income information for the previous year, at the individual and family level. Many different individual and family outcome measures are considered including work at all, work full-time full-year, number of weeks worked, average hourly earnings, annual hours, annual earnings, family earnings (head and spouse), family transfer income, and total family income. All measures are annual and correspond to the calendar year previous to the survey. Full-time is defined as those working at least 35 hours per week last year, and full-year is defined as those working 50 or more weeks last year. The ADF data is available beginning with the 1964 survey year. Because of major changes in the survey beginning in 1976, this study uses the 1976-1998 surveys covering years 1975-1997.2 The sample size is approximately 150,000 persons per year.

The earnings data is topcoded in both surveys. In the ORG data, weekly earnings are topcoded at

\footnotetext{
${ }^{1}$ The data is available through 1995 . However 1994 and 1995 data were dropped because the variables identifying MSAs appear to be incorrect

${ }^{2}$ Prior to the 1976 survey year, weeks worked last year was a categorical variable and usual hours worked per week last year was not available. Hours worked last week was available, but is a noisy measure of hours worked last year.
} 
$\$ 999$ through 1988 , and $\$ 1923$ from 1989 on. In the ADF data, annual earnings are topcoded at $\$ 50,000$ through 1981, $\$ 75,000$ from 1982-1984, $\$ 100,000$ from 1985-1988, and about $\$ 200,000$ from 1989 on. Following Katz and Murphy (1992) and more recently Blau (1998), the earnings of topcoded individuals are adjusted to be 1.45 times the topcoded value. Beginning in 1996, instead of giving each topcoded observation the value of the topcode, the CPS assigns the mean among the sample of topcodes (by demographic group). The earnings figures can be as high as $\$ 600,000$ in this period. I make no adjustment for topcoding in these years. There is no apparent topcoding of family earnings or family income. Real earnings and income are constructed using the CPI-U-X1 deflator.

For most of the analysis, the micro-data is collapsed into cells defined by MSA, year, and skill group. Skill groups are defined by education $(<12,12,13-15,16+$ or $\leq 12,>12)$, race (white, nonwhite), and sex. The nonwhite group includes both blacks and white Hispanics. The ORG data identifies 44 MSAs, while the ADF data (beginning a few years earlier) identifies 35 MSAs. In order to better approximate labor market areas, the MSAs are combined in their consolidated MSA (CMSA) units where applicable. Examples of CMSAs include New York, Los Angeles, and Chicago. The final sample includes $35 \mathrm{MSA} / \mathrm{CMSAs}$ in the ORG data and $27 \mathrm{MSA} / \mathrm{CMSAs}$ in the ADF. ${ }^{3}$ For the remainder of the paper, these geographic unites will referred to as MSAs. Based on 1990 population figures, my MSA sample accounts for about 60 percent of the total metropolitan population or 50 percent of the total population. The sample accounts for virtually all of the metropolitan population in 1975 . The median MSA in the ORG data contains about 200 observations per year, compared to about 75 observations per year in the ADF. Once the cells are further refined to skill groups, some cells get very small. When possible, data are combined into two year periods to reduce the problem of small skill group-MSA-year

${ }^{3}$ Considerable effort was made to insure that the MSAs were comparable units over time. For example, It is relatively common for an MSA to split into two. The split off MSAs were combined making the series comparable over time. However, some MSAs grow over time as additional areas are added to an existing MSA. These changes can not be addressed. Fortunately, changes in MSA definitions occur only once per decade, following the decennial census. These "seam years" were dropped from the analysis in sensitivity tests. 
cells. All analyses in the paper are weighted using the person weight.

The same sample selection criteria is applied to both the ORG and ADF data. The sample includes persons between 22 and 62 years old. I exclude the self-employed, those working without pay, and those with positive earned income but zero hours of work. Following Katz and Murphy (1992), individuals with real weekly earnings of less than $\$ 67$ in 1982 dollars (i.e. one half of the value of the minimum wage assuming a 40 hour work week) were excluded. The final sample has about 220,000 person observations per year in the ORG sample and 70,000 observations per year in the ADF sample. The unit of analysis in the ORG data is the individual.

\section{Trends in Labor Market Outcomes Among Skill Groups}

As a starting point, this section presents simple time series trends in labor market outcomes by education, race and sex. In the interest of space, the discussion uses only the ADF data. The analysis introduces some of the labor market outcomes that will be used in the empirical analysis. This analysis is a starting point for characterizing the trends in the outcomes variables and how they vary across different groups. Using these simple figures to make comparisons across groups in their responsiveness to cycles, however, may not be possible because of the difficulties in separating secular trends from cycles. Therefore, these results should be viewed as only first step.

\section{$\underline{4.1 \text { Definitions }}$}

Skill groups are defined by education, race and sex. Low skill workers are typically defined using education level and most often include persons with less than a high school education. This analysis uses data covering a period of three decades and is concerned with making comparisons across groups over time and cycles. It is important for the analysis that the skill groups are defined to be comparable over time. However, education levels have been rising over time for all demographic groups, and this shows up most dramatically at the lowest levels of educational attainment. In the presence of 
rising education levels, even if the distribution of earnings and income are unchanged over time, then one would expect that the relative position of low educated persons (e.g. high school dropouts) would decline over time. That is, over time, this group would become more and more disadvantaged.

Figure 1 presents trends in the percent of persons with various education levels in the ADF sample, by race and sex. This figure shows that the percent of persons with less than a high school education has fallen dramatically in this period. Between 1975 and 1997, the percent of white men with less than a high school education declined from 25 percent to less than 10 percent. For nonwhite men, the percent with less than a high school education declined from 50 to 30 percent. At the same time, among whites, the percent with a high school diploma has held steady while those with greater than a high school diploma has increased. Among nonwhites, both high school and more than high school groups are increasing. ${ }^{4}$

In the presence of these dramatic increases in education levels over this period, the main analyses in this paper will compare those with a high school education or less to those with more than a high school education. Those with a high school education or less are defined to be less skilled workers. This group will be less disadvantaged group than high school dropouts, however, and where possible I examine outcomes across all four education groups $(<12,12,13-15,16+) .^{5}$

\subsection{Trends in Employment. Earnings and Income using ADF}

Figures 2a presents trends in employment to population ratios for men for 1975-1997 by race and education. There are two definitions for the employment to population ratios. The Any-Work EPOP is the employment to population ratio where a person is considered employed if they worked at all last year.

${ }^{4}$ Beginning in the 1992 survey, the CPS records the degree earned rather than the years of schooling completed. As is evident in the figure, this decreases the percent with a high school diploma, and increases the percent with greater than a high school diploma.

${ }^{5}$ An alternative approach is to define skill groups by their relative position in the earnings or wage distribution (i.e. less than the 20th percentile). Because this analysis is not limited to workers, skill groups would have to be assigned using predicted wages. This may be examined in future work. 
The FTFY EPOP is the employment to population ratio where a person is considered employed if they worked full-time (at least 35 hours) and full-year (at least 50 weeks) last year. In each page, the left two graphs are for whites and the right two graphs are for nonwhites. The top figures present the Any-work EPOP and the bottom row of figures presents the FTYR EPOP.

As expected, EPOP ratios are higher for those with higher education levels. Less educated nonwhites tend to have higher EPOP ratios than whites. Among men with less than a high school education, the Any-work EPOP is declining significantly over this period. By the mid-1990s, fully 30 percent of men are not working at all over the year. This undoubtedly is in part due to the changing composition of the lowest education group over this time period. More relevant for this analysis are the cyclical trends in these ratios. The figures suggest that employments rates of those with lower education levels and nonwhites exhibit more cyclical variation. During this period, unemployment rates peaked in 1982 and 1992. There seems to be more cyclical fluctuation in the full-time employment rates (FTYR $E P O P)$ than the any work employment rates $(A n y$-work EPOP). For nonwhites with less than a high school education, the Any-work EPOP also varies significantly over the cycle. This is striking given that the measure is any work in the entire calender year. The high rates of non-work in trough of the recession is consistent with the persistently high unemployment rates for this group. It should be noted that some of the variability in the measures for nonwhites reflect small sample sizes, especially for higher education groups.

Figure $2 \mathrm{~b}$ presents trends in annual hours and earnings for men. The figures have the same format as above with whites on the left and nonwhites on the right. The top row of Figure $2 \mathrm{~b}$ shows mean annual hours worked and the bottom row shows mean annual earnings. It is important to note that these earnings and hours figures are averages over all individuals in the race-education-sex-year group, and includes workers and nonworkers. Therefore, the change in earnings is comprehensive and may vary due to changes in changes in hours, weeks, hourly wages, as well as changes in the composition of the 
work force.

In general, the pattern for annual hours worked is similar to the trends for the EPOP ratios. These figures show that, to a greater extent than in other measures, both annual hours and real annual earnings show cyclical variation for college educated white men. While the average hours and earnings of less educated individuals also show cyclical variation, the relative variability of low versus high education groups is less dramatic than the employment figures. In graphs not presented here, the variation in annual hours worked comes more from variation in weeks worked per year than from hours worked per week. That may be due to measurement error in hours worked per week or it may reflect that nature of employment reductions that firms engage in. ${ }^{6}$

Figures $3 \mathrm{a}$ and $3 \mathrm{~b}$ present similar figures for women. These figures show that employment and earnings for women are increasing secularly over this period for all groups, but at a substantially slower rate for women with low education levels and nonwhites. These trends dominate all of the figures and it is difficult to make any inferences about the variation over the business cycle.

Although not shown here, family earnings and family income also show cyclical variation.

Family income, and to a lesser extent family earnings, shows less variability across demographic groups compared to the fluctuations in individual earnings. Our empirical model will explore the reasons for this difference.

\section{Empirical Model}

The goal of this analysis is to estimate how individuals in different demographic groups are affected by changes in macroeconomic conditions. One approach to estimating this effect is to take the time-series trends presented above and regress the outcomes on a measure of the business cycle such as

${ }^{6}$ Figure $2 \mathrm{~b}$ shows that average earnings for college educated white men increased substantially starting in 1995. This is due to the change in the topcoding in the CPS. I examine the sensitivity to dropping these years in the subsequent analyses. 
the unemployment rate. This approach is not taken here for two reasons. First, aggregate measures of business cycles do not necessarily capture the relevant cycle if there is area variation in the timing or severity of the cycle. Second, the unemployment rate (or some other aggregate measure of employment) can be mechanically related to the dependent variable (e.g. the EPOP ratio for less skilled persons). This reflection or endogeneity problem makes the interpretation of such estimates difficult. One approach used in the literature is to use instruments to identify the effect (Bound and Holzer 1993, 1995). As an alternative, this analysis treats the shock to a local area as unobserved and compares the response to the shock among different groups. This avoids the reflection problem and has the added advantage of differencing out an MSA effect. All of the comparisons across groups are made within MSAs which takes advantage of the wide regional variation in the timing and severity of recessions.

For this and all remaining analyses in the paper, I start with collapsing the data into cells defined by MSA $(m)$, time $(t)$, and skill group $(j)$. Let $y_{j m t}$ be the mean of a given labor market outcome for group $j$ in area $m$ in year $t$. Suppose one could observe some exogenous measure of the business cycle in the MSA in time $t$, represented by $y_{m t}$. Putting the variables $y$ in logs, one could characterize the $\log$ of the mean labor market outcome for group $j$ in MSA $m$ in period $t$ by the following equation:

$$
\ln \left(y_{j m t}\right)=\alpha_{0 j}+\alpha_{j} t+\delta_{t}+\mu_{m}+\gamma_{j} \ln \left(y_{m t}\right)+\epsilon_{j m t}
$$

The labor market outcome of group $j$ is a function of permanent differences across groups $\left(\alpha_{0 j}\right)$, a skill group specific trend $\left(\alpha_{\mathrm{j}}\right)$, permanent differences across areas $\left(\mu_{\mathrm{m}}\right)$, overall time effects $\left(\delta_{\mathrm{t}}\right)$, and a "cycle" measure $y_{\mathrm{mt}}$. Note that the coefficient on $\mathrm{y}_{\mathrm{mt}}$ varies with group so the effect of MSA fluctuations can differ across the groups. The key parameters are the $\gamma_{j}$ 's.

If the equation is differenced (thereby purging the permanent MSA and group effects) over some time period $t$ then the equation becomes: 


$$
\Delta \ln \left(y_{j m t}\right)=\alpha_{j}+v_{t}+\gamma_{j} \Delta \ln \left(y_{m t}\right)+\epsilon_{j m t}
$$

Now, $\Delta \ln \left(y_{m}\right)$ represents the shock to a particular MSA in time $t$. The problem with estimating this equation is finding an exogenous measure of the shock $\Delta \ln \left(y_{m}\right)$. The approach used here is to treat the shock as unobserved and estimate each of the $\Delta \ln \left(y_{m}\right)$ as parameters. I therefore estimate the following equation:

$$
\Delta \ln \left(y_{j m t}\right)=\alpha_{j}+\gamma_{j} \beta_{m t}+\epsilon_{j m t}
$$

The $\beta_{m t}$ are the parameters capturing the shock to MSA $m$ in period $t$. The model is identified by the assumption that the responsiveness across skill groups $\gamma_{\mathrm{j}}$ is constant across MSAs. ${ }^{7}$ The main interest of the paper is to compare the $\gamma_{\mathrm{j}}$ in order to determine the relative responsiveness across groups. The model can be extended to look for structural changes in the intercepts (skill group trends) and slopes (skill group responsiveness to cycles) over time and, to some extent, across space. The approach is a simple way to allow for comparisons between multiple skill groups over multiple time periods.

The analysis will use many alterative individual and family outcomes in order to fully characterize the impact of cycles on different groups. Accordingly, model (3) is estimated for each of the outcomes of interest. First this estimation is done one equation at a time. In this estimation, the parameters capturing the skill group response to the shock $(\gamma)$ have to be normalized to fix the scale of the estimated shock parameters $(\beta)$. We choose a "reference" skill group and normalize the $\gamma$ for that group to 1. The parameters for the other skill groups are interpreted as the response relative to the

${ }^{7}$ This approach is feasible due to the use of multiple skill groups. The number of observations are $\mathrm{J}^{*} \mathrm{M}^{*} \mathrm{~T}$ where $\mathrm{J}$ is the number of skill groups, $\mathrm{M}$ is the number of MSAs, and $\mathrm{T}$ is the number of time periods. There are $M^{*}$ T nuisance parameters, one for each year in each MSA. In practice I have 8 skill groups which turns out to be more than enough to estimate the parameters precisely. Note that by estimating MSA-time specific effects, the time effect $v_{t}$ drops out of the equation. These parameters may not be consistent because with each additional period $\mathrm{T}$, $\mathrm{M}$ (number of MSAs) additional parameters must be estimated. 
response for the reference group. In addition, the intercept for the reference group is set to 0 , so the intercepts for the other skill groups are interpreted as the average trend for group $j$ relative to the trend for reference group.

This estimation does not take account of the fact that the MSA-time "shocks" $\left(\beta_{\mathrm{mt}}\right)$ enter each of the labor market outcome equations. Therefore I also estimate the models by pooling the equations and constraining the $\beta_{\mathrm{mt}}$ to be equal across the equations. This "pooled" model has three advantages. First, only one normalization on the $\gamma$ 's is necessary across all the equations. We can therefore not only examine how the sensitivity to cycles varies across groups, but how it varies across different outcome variables. Second, there may be efficiency gains to accounting for the common parameters across the equations. Third, conceptually it is attractive to think of a single "shock" to an area which is then filtered down to different outcomes (e.g. hours, earnings, income) and different groups. ${ }^{8}$

While the model in (3) in logs, in practice I examine the models using both changes in logs and changes in levels. The change in the logs is attractive because of the interpretation as percent changes in the variable. In practice, we do not know if the correct form for the model is in levels or logs. Because the mean levels of the outcomes vary substantially across the groups, the estimates of the $\gamma$ can be significantly biased towards finding greater responsiveness to cycles for less skilled groups if the model is mis-specified. ${ }^{9}$ We will investigate the sensitivity to this assumption in the estimates below.

These regressions are estimated using both the ORG and ADF data. Skill groups are defined by

${ }^{8}$ Note that even though the shocks are equivalent across equations, the parameters can not be "added up" across equations. That is because the dependent variable is the change log of the mean within a cell. Specifically, even if $y=y_{1} * y_{2}$, the $\log$ of the mean of $y$ does not equal the $\log$ of mean of $y_{1}$ times the $\log$ of the mean of $y_{2}$.

${ }^{9}$ To see this point, assume that the true model is linear in the changes in levels. Then (dropping the MSA subscript) equation (3) becomes $\Delta y_{j t}=a_{j}+g_{j} \Delta y_{t}+e_{j t}$. Let $y_{j}$ denote the mean level of $y_{j t}$ and $y$ denote the mean level of $y_{r}$. Then the equation can be transformed to be $\Delta y_{j t} / y_{j}=a_{j} / y_{j}+g_{j} *\left(y / y_{j}\right) \Delta y_{i} / y+e_{j t} / y_{j}$. Using an approximation for the $\log$, this implies that $\Delta \log \left(y_{j t}\right)=\alpha_{j}+\gamma_{j} \Delta \log \left(y_{t}\right)+\epsilon_{j t}$, where $\gamma_{j}=g_{j} *\left(y / y_{j}\right)$. So if group $j$ has a low mean of the variable $y$, then the estimated $\gamma_{j}>1$ even if (the true) $g_{j}=1$. I thank Joe Altonji for pointing this out and Dave Card for helping to formalize it. 
education, race and sex. There are a total of 8 skill groups $(2 \operatorname{sex} * 2$ race $* 2$ education). With the exception of average hourly earnings (which is averaged over workers) all variables are constructed as means over the entire population in these cells using the CPS sample weights. To increase cell sizes (which is important for nonwhites), the data are grouped into two year periods.

The variables used in the analysis include: employment rates, hours worked, earnings, average hourly wage, as well as family measures such as head's earnings, spouse's earnings, transfer income and other family income. Each of these variables is averaged into the cells using the characteristics of the individual (e.g. sex, education, race). Therefore, the entire analysis is based on individuals, even though some of the measures are "family" based measures. I do this so that I can directly compare the results for individual and family outcomes. The alternative is to create cells using observations on families, using the head's characteristics to define the cell. This makes it difficult to connect the individual and family measures. ${ }^{10}$

The two education groups are those with a high school education and less, and those with more than a high school education. The choice of two education groups (compared to the four groups used in the aggregate analysis) is made for two reasons. First, and most importantly, I argued above that with increases in education levels, the group with less than a high school education is becoming more disadvantaged over time. This showed up quite dramatically in the simple trend graphs presented above. By choosing somewhat broader education classes, I hope to minimize the problems with making over time comparisons with a group whose composition is changing. The down side of this approach is that the "low" education group is not that low, and this will probably attenuate the differences between low and high skill groups. Second, the use of four education groups leads to very thin cells, especially with

\footnotetext{
${ }^{10} \mathrm{In}$ an earlier version of this paper, I used the family-based analysis to analyze the family variables. Following Karoly (1992) and others, I create adjusted family measures by dividing by the family's poverty threshold. This adjusts for family size using the implicit equivalency scales which account for age structure and economies of scale. Neither of these adjustments changed fundamentally the results from what is reported here.
} 
nonwhites.

\section{Preliminary Analysis of Differences Across Low and High Skill Groups}

As a preliminary analysis, the differences across groups are explored using graphs that plot $\Delta \ln \left(y_{j m}\right)$ for a particular low skill group $j$ against the $\Delta \ln \left(y_{m m}\right)$ for a "reference group" $r$ for a given time period $t$. This approach can generate simple comparisons between the sensitivity of employment, earnings and income of less skilled groups to high skill groups. The presentation here will be limited to the ADF file.

In particular, I look at changes between the trough and peak a given cycle. All of the figures in this section use the 1982 recession as the cycle, measured as the change from 1979 (previous peak) to 1982 (tough). The 1982 recession is chosen because it was the most severe recession in the period covered in the CPS data. The reference group for all figures is high education white men (those with greater than a high school education), chosen because they appear to be the group with the least sensitivity to cycles. This approach is best applied to groups that are not experiencing significant trends over time. It can be difficult to extract the cycle from the trend in this simple analysis. Consequently, in this section, I present graphs only for men. The regression results, presented in the next section, provide estimates for all 8 skill groups ${ }^{11} 12$

All of the graphs have the same form. First consider the top left graph of figure 4. Each point on the graph represents a pair for an MSA. On the y-axis is the change in the log of the Any-Work EPOP

\footnotetext{
${ }^{11}$ One could in principle de-trend the data for women before plotting the data. Another possibility is to control for the trend by using high skill women as the reference group for women. Both of these approaches were implemented but, in part to keep this section brief, the discussion of women is postponed until the regression results.

${ }^{12}$ As mentioned above, the CPS data is combined into two year periods to increase the number of observations in each cell. Still, some of the nonwhite skill groups have very few observations in some of the smaller MSAs. For the graphs, a cell is only included if there are at least 20 observations per cell. On average, this drops about 5 MSAs on the nonwhite graphs.
} 
(last year) for white men with a high school education or less (the low skill group). On the x-axis is the change in the log of the same EPOP measure for the reference or high skill group defined as white men with more than a high school education. The figures differ only in the choice low skill group and labor market outcome. The top right graph compares the change in Any-Work EPOP for nonwhite men with a high school education or less to the reference group. The bottom row of graphs presents the same analysis for the FTYR EPOP. The points on the graph are weighted to reflect the size of the MSA. The larger the circle, the larger the MSA.

Each graph includes a 45 degree line to make the comparison between groups easier. If the points generally lie below the 45 degree line, than the percent change in the outcome for the less skilled group is greater (more negative) than the change in the outcome for the high skill group. If the points are clustered on the line, then the responses are similar. A point above the 45 degree line means a larger response among the high skill group than the low skill group.

One advantage of this approach is that it makes use of rich variation across labor markets in the U.S. As an illustration of this, Table 1 compares the outcomes across MSAs in the 1982 and 1992 recessions. In particular, I measure the change in the log of the male employment to population ratio for any work (Any-work EPOP) last week based on the ORG data for each MSA from 1979-1982 and 19891992. For each of the two time periods, the table presents the MSAs with largest and smallest percent changes over the period. The 1982 recession hit the industrial Midwest hardest. For example Detroit, Pittsburgh and Cleveland had reductions on the order of 10-15 percent while San Francisco, New York and Boston experienced reductions of only 1-3 percent. In the 1992 recession, on the other hand, reductions on the order of 7 to 10 percent were experienced in San Diego, Boston and New York and the effect in the industrial Midwest was relatively mild.

Returning to Figure 4, several observations can be made. Looking at the Any-work EPOP graph shows that white men with low education levels have fluctuations in employment rates that are fairly 
similar to white men with high education levels. Most of the observations are clustered on the 45 degree line. The same is not true for nonwhite men. The figures on right suggest that nonwhite men are significantly more impacted by the negative shock in this period than the reference group. Note that almost all of the observations lie below the 45 degree line. In many cases their percent change in the EPOP ratio is many times larger than the rate for the reference group. Using FTYR EPOP, both white and nonwhite low skilled men appear to be more negatively impacted by the 1982 recession than white high skilled men. Within the low skill group, nonwhites appear to be significantly more affected than whites. The difference between the races is particularly evident with the Any-work EPOP.

Figure 5 repeats the analysis and compares the change in the log of mean annual hours worked (top row) and mean annual earnings (bottom row) for low skill to high skill men. Recall that annual earnings is averaged over both workers and nonworkers and thus reflects changes in employment, hours per week, and wages. This figure shows that white and (especially) nonwhite low skill men show larger reductions in hours and earnings than white high educated men. These patterns are similar to that found above FTYR EPOP. In figures not shown here, family income and family earnings also show greater responsiveness among low skilled men. The differences between groups appear, however, to be smaller than that found for annual earnings. This is likely to reflect the ongoing increases in employment and earnings among married women, evidence of secondary workers entering the labor market to replace the recession-induced lost earnings of the primary earner, or the counter cyclical pattern for transfers for low skill groups. These patterns are explored further below.

\section{Regression Results}

The preliminary analysis above shows that low skill men were more impacted by the 1982 recession than high skill men. Within skill groups, nonwhites are affected more adversely than whites. These results, while illustrative, are somewhat qualitative and may be sensitive to the presence of trends 
for skill groups. In addition, the results speak to one particular time period, and do not take full advantage of the differences in the timing of cycles across areas. This section extends the analysis by providing estimates of equation (3) above using the full time periods covered in the data. This approach uses year to year changes to take full advantage of the variation in the timing of the economic changes across areas.

The observations for the regressions are the cells defined by skill group, MSA, and time. There are 6 time periods and 35 MSAs in the ORG data and 10 time periods and 27 MSAs in the ADF data. ${ }^{13}$ With 8 skill groups, this yields a total of 1680 observations in the ORG and 2160 observations in the ADF. The reference group for all regressions is high education ( $>12$ years of education) white men. All models are estimated using weighted nonlinear least squares using the cell's weighted count of individuals. The precision of the estimate of the dependent variable varies with the size of the cell, and the weights will down-weight the small cells. No cells are dropped from the analysis.

\subsection{Results for Weekly Measures using ORG Data}

We being by presenting estimates using the ORG data and estimate each labor market outcome equation separately, without accounting for common MSA shock across the equations. The results for these "single equation" estimates are in Table 2. Each column in the table corresponds to estimates for a different equation, and they differ only in the definition of the dependent variable. The table only reports the parameter estimates for the $\gamma$ 's (relative impact of the shock across skill groups). Because the MSA-time shock, $\beta_{\mathrm{m}}$, is unobserved and estimated as a parameter, some normalization must be made to fix the scale. In these initial regressions where each equation is estimated separately, we normalize the parameter for the impact of the cycle on the reference group to $1\left(\gamma_{1}=1\right)$. The parameters for the other

\footnotetext{
${ }^{13}$ For the analyses of both data sets, the data are combined into two year periods. The ORG data cover 1979/80 - 1991/92. 1993 was dropped because there was no year to pool it with. The ADF data cover 1975/761995/96 with 1997 dropped. After differencing the data, there are 6 time periods in the ORG (1981/82 - 1991/92) and 10 time periods in the ADF (1977/78 - 1995/96). By combining two years, the resulting first differences span on average a two year change.
} 
skill groups are interpreted as the response relative to the response for high skill white men. In addition, the intercept for the reference group is set to 0 , so the intercepts for the other skill groups are interpreted as the average trend for group $\mathrm{j}$ relative to the trend for high skill white men.

The ORG data describes the nature of your work last week. Table 3 shows three measures. The Any-Work EPOP is the employment to population ratio where a person is considered employed if they worked at all last week. The FT EPOP is the employment to population ratio where a person is considered employed if they worked full-time (at least 35 hours) last week. Lastly, mean real weekly earnings are used. Columns (1) and (2) present estimates where the EPOP is specified as changes in logs. Columns (3) and (4) estimate these models using changes in levels of EPOP. Column (5) presents estimates for changes in log weekly earnings. The statistical significance of the parameters are determined by testing whether the coefficient is significantly different than 1 (e.g. no differences across groups). The significance tests in all of the tables refer to that null hypothesis.

The results in columns (1) and (2) show that there are sizeable and statistically significant differences in the responses to cycles across skill groups. The results in column one show that, for a given shock, the fluctuation in the Any-work EPOP is 1.4 times greater for low skill white men and almost 4 times greater for low skill nonwhite men than the response for high skill white men. The results for FT EPOP (column 2) are generally similar the Any-work EPOP. The results for women show that the employment and earnings of high skill white women show significantly less cyclical fluctuation than all groups, including high skill white men. That may be due to differences in the industries and occupations that men and women are working in. Alternatively, it may also reflect the fact that women may act as "added workers" who enter the labor force in recessions to make up for lost earnings of the principle earner. These issues will be explored at more length below. Low skilled nonwhite women are the most severely impacted by cycles. The results in columns one and two show that, for a given shock, their employment rates fluctuate 5 times as much as high skill white men. 
These large parameters for low educated women are attenuated somewhat when the models are estimated in levels instead of logs. These estimates are shown in columns (3) and (4). As discussed earlier, if the level model is correct, then the low mean employment rate among these groups (e.g. FTYR $E P O P$ rates for less educated women are 0.42 for whites and 0.37 for nonwhites) will lead to larger parameters for those groups. Some of these impacts are significant. The most extreme example is coefficient for low skill nonwhite women which, in the Any-work EPOP is reduced to 1.44 from 5.42 . For the remainder of the paper, I rely on the more conservative level equations for EPOP regressions. ${ }^{14}$

The results in column 5 show that the differences across skill groups are smaller when using real weekly earnings. In a given period, the percent change in real weekly earnings of white low skill men is 1.2 times as large and the change for nonwhite low skill men is about 2 times as large as that experienced by white high skill men. This may reflect greater rigidities in wages for low skill workers. For example, if equilibrium wages rates are driven down in recessions, to the extent that the minimum wage creates an wage floor for low skill workers, the reduction in earnings for low wage workers will be smaller, relative to high skill workers, than their reduction in employment. Alternatively, this may reflect how the composition of workers changes over the business cycle and how this compares across skill groups. This point has been discussed in the empirical literature on cyclical behavior of real wages (for example see the recent paper by Solon et al, 1994).

The estimates from pooling the three equations for the ORG data are presented in Table 3. The top portion of the table presents the $\gamma$ parameters along with their standard errors for each skill group. Note that only one normalization is needed to identify the model. Here we normalize the coefficient for high skill white men to 1 in the Any-work EPOP equation. All of the coefficients are now relative to that group's outcome. Looking across the columns one can see how the fluctuation of one measure compares

\footnotetext{
${ }^{14}$ The results for changes in levels of earnings generated similar results to changes in logs (not shown here). The changes in logs will be used for the rest of the study.
} 
to another. Overall mean weekly earnings vary the most across the cycle for all groups, followed by the FT EPOP and then the Any-work EPOP. For example, for low educated nonwhite women, the response in mean earnings is three times as large as the response for employment rates. In order to better compare the results to the "single equation" estimates in Table 2, the bottom portion of the table divides each parameter by the estimated $\gamma$ for the reference group in that equation. The statistical significance refers to testing whether these parameters (in the bottom portion of the table) are significantly different from 1.

Comparing the estimates in the bottom portion of Table 3 to the estimates in Table 2, very similar patterns emerge. Nonwhites and less educated workers experience fluctuations larger than other groups. Even within education groups, nonwhites fare worse than whites, possibly reflecting their more disadvantaged status. White women in both high and low education groups experience less cyclical variation than all other groups. Nonwhite less educated women exhibit more fluctuation, but less than their male counterparts.

All remaining regression models will be estimated using the "pooled model". This does not change the qualitative results significantly.

\subsection{Results for Annual Measures using ADF Data}

The ADF data allows for two important extensions to the analysis of the ORG data. First, I examine more comprehensive measures of employment corresponding to activities over the past year thereby getting at changes in the duration and intensity of employment. Second, I can examine family measures in addition to individual measures. The family is the key economic unit and, for policy purposes, an analysis limited to individuals would be incomplete. An analysis of families may differ from one of individuals in that families contain varying numbers of potential workers with differences in propensities for intra-family substitution of labor market activity.

The results for the ADF are presented in two tables. Table 4 presents the results for individual labor market outcomes (FTYR EPOP, annual hours, annual earnings, and hourly wages) and table 5 
presents the results for the family outcomes (head's earnings, spouse's earnings, other family income, and family earnings and income). ${ }^{15}$ In each table, a "pooled model" is estimated and the parameter for the reference group in one equation is normalized to one. The format of the tables are identical to Table 3 , with estimated parameters and standard errors in the top portion of the table, and adjusted parameters along with tests for statistical significance (different from 1) in the bottom portion of the table.

Looking at the top portion of Table 4, the magnitude of changes in annual earnings are larger than annual hours or employment rates. This is not surprising as annual earnings captures changes in employment and hours worked. Average hourly wages (averaged over workers) are, along with the other measures, pro-cyclical. This is consistent with the more recent real wage studies. The bottom portion of Table 4 provides estimates of the relative responsiveness across groups. This shows similar patterns to those with the ORG data. The responsiveness to a shock is higher for those with lower education levels and nonwhites, and lower for high educated white women. The results are particularly striking when you compare white and nonwhite low educated groups. For both men and women, nonwhites are significantly more impacted by business cycles than whites. For example, the equation for mean annual hours worked shows that white low skilled men are 1.3 times more affected than high skill white men, while nonwhite low skill men are more than 3 times more affected. ${ }^{16}$

Similar to the ORG, the results for earnings show smaller differences across groups than the employment measures. Again, this may reflect differences across groups in the types of workers who experience unemployment (or reductions in hours) or differences in wage rigidities between high and low skill workers. This can be examined more directly by looking at the estimates for the equation for the

\footnotetext{
${ }^{15}$ For the purposes of this analysis, the "head" is defined as either the head of the CPS family or subfamily (if the person is part of a family), or the individual themselves if they are an unrelated person of secondary individual. In married couples, the man is always assigned to be the head. If there is no spouse in the family, a value of 0 is used.

${ }^{16} \mathrm{We}$ also estimated models with Any-work EPOP. Those estimates show large but no statistically significant differences across groups.
} 
average hourly wages (column 4). Most of the parameters are less than one and imply that the cyclical fluctuations in the wages of high skill white men are larger than that found for nonwhites, women and less skilled workers. This dampens the differences across groups in annual earnings.

The estimates for the pooled models of family outcomes are presented in Table 5. Family income is disaggregated into head's earnings, spouse's earnings, and other family income. Other family income includes transfers, capital income, and earnings of other family members. The table also includes summary measures for family earnings and family income. Individual annual earnings are also included to provide some reference to the earlier tables on individual outcomes. ${ }^{17}$ Examining the top portion of Table 5 shows that the earnings of heads is less variable than overall earnings. Comparing head's earnings (column 1) to family earnings (column 5) shows that in the most disadvantaged groups (nonwhite or less educated) there is little evidence of labor substitution among family member as family earnings fluctuates more than head's earnings. Among more skilled families (high educated whites) family earnings fluctuates less than head's earnings. That can be seem more directly by the small coefficient on spouse's earnings for high educated, white groups. Transfers tend to reduce the size of the shock, which can be seen by comparing the estimates for family earnings and family income.

By examining the bottom portion of the table, with parameters normalized to 1 for the reference group in each equation, one can compare how the different family measures impact groups differentially. In general, these figures match the general pattern of findings thus far. Those with lower education levels and nonwhites show greater responsiveness to cycles than the high skill and white groups. The most striking results exist for spouse's earnings, with much greater fluctuations for low educated nonwhite, and to a lesser extent white, individuals. This is in part due to lower marriage rates in these groups, but may also reflect differences in the propensity for women to be "added workers".

\footnotetext{
${ }^{17}$ Note that the parameter estimates for individual earnings in Table 5 do not match exactly the parameters in Table 4. That is because different equations were estimated, which generates somewhat different estimated MSA shocks. The coefficients are quite comparable.
} 
Including non-labor income has a significant impact on the differences in cyclical responses across skill groups. In general, the gaps between groups narrow when considering family income (column 6). This pattern was also found by Blank (1989) and Blank and Card (1993). The reduction in volatility is especially evident for nonwhite less skilled individuals. For example, family earnings of less educated nonwhite women fluctuate three times as much as the reference group, but their family income fluctuates only 2.5 times as much as the income of the reference group. This is a 15 percent reduction. In analyses not shown here, the reduction in the impact of cycles on low skill families comes from receipt of counter-cyclical government transfers such as welfare and unemployment assistance. ${ }^{18}$

\section{$\underline{7.3 \text { Discussion }}$}

The results from the analysis of the ORG and ADF data show consistently that, relative to high skill white men, nonwhites and those with low education levels have greater fluctuation in cycles. Highly educated white women are the only group that consistently shows lower responsiveness compared to the reference group. Here we explore why. First, some groups may be less tied to the labor market and may rely on government transfers or the labor earnings of other family members. Another hypothesis is that the jobs held by individuals in these groups vary in ways that would lead to expected differences in employment fluctuations. It is fairly well established that jobs in construction and manufacturing, laborers, younger workers, and those in non-union employment experience more employment fluctuations, while jobs in the public and FIRE (finance, insurance, and real estate) sectors, managerial jobs, and union jobs experience less employment fluctuations.

These possibilities are explored in Table 6, which presents means of some of these variables for each of the skill groups used in the analysis. The patterns in the table match in many ways the patterns found in the regressions. For example, highly educated white women, the least responsive group, are

\footnotetext{
${ }^{18}$ I explored estimating models with more dissaggregated measures of family income such as various transfers. In practice, few families receive these transfers and most of the parameters were not statistically significant.
} 
least likely to be in construction and manufacturing and are much more likely to be in retail trade, FIRE, and public sector jobs. They are also more likely to be in managerial and professional jobs, and less likely to be in operator/laborer positions. Nonwhite less educated men, on the other hand, are the most represented in construction, manufacturing, laborer positions, and have the lowest union participation rates. This simple analysis gives mixed evidence for nonwhite less skilled women, found to be the most responsive group. On the one hand, they have the highest rates of nonattachment to the labor market and highest welfare reliance which would smaller cyclical fluctuations. On the other hand, those that are employed are more likely to be in manufacturing and in laborer positions, which would lead to higher rates of cyclical fluctuation.

\section{$\underline{7.4 \text { Extensions }}$}

All of the regression results hold the skill group responsiveness to be fixed over the entire time period. The two major business cycles covered in the data, the 1982 and 1992 recessions, differed a great deal in which industries and occupations were most impacted. Farber (1997), using data from the Displaced Worker Surveys, shows that in the early 1990s displacement rates among higher educated workers increased relative to those with lower education levels. The impacts of changes over time in the relative responsiveness is explored in this section using the ADF data. First, graphs comparing high and low educated men are presented for the 1989-1992 period which can be compared to the earlier graphs for 1979-1982. Second, the regressions are estimated allowing for different skill group parameters for the years 1975-1988 versus 1990-1996.

Figure 6 presents changes in the log of mean annual hours and earnings for low skill men compared to the reference group, high skill white men. Comparing this to Figure 5, the comparable figure for 1979-1982, several important differences emerge. First, the effect of the downturn on the low skill group is much closer to the effect on high skill group. The MSA observations are clustered much closer to the 45 degree line (the line of equal effects). Second, this feature is found for both whites and 
nonwhites, although more so for whites.

This is explored further in Table 7. The table reports results for equations for individual earnings, family earnings and family income and uses the same pooled model as above. The only difference is the addition of a set of skill group specific cycle parameters that apply to the post-1988 period:

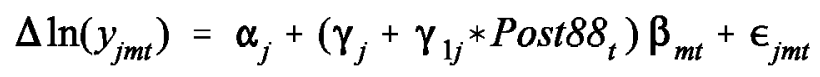

The coefficients $\gamma_{1 \mathrm{j}}$ represent the change in the responsiveness between the early and later periods. 1988 is chosen as the break year because it is the end of the recovery from the 1982 recession. The top portion of the table presents the cyclical responsiveness parameters for the overall period $\left(\gamma_{\mathrm{j}}\right)$ and the bottom portion presents the parameters for the difference between pre and post 1988 period $\left(\gamma_{1 j}\right)$. There are two normalizations in the pooled model, one for the overall period and one for post 1988 period. As above, the coefficient for high skill white men in the overall period is normalized to 1 . In addition, the parameter capturing differences between pre and post 1988 period is set to 0 for this group. In the bottom of the table, I also include renormalize all of the coefficients by subtracting the value for the reference group. These are in italics. The statistical significance tests are that the top panel figures are different from 1 and the bottom panel figures are different than 0 .

These results fairly consistently show that the relative responsiveness of cycles by the low skill groups has declined relative to high skill white men over this time period. That is, all coefficients are negative in the bottom of the table. This is consistent with Farber (1997). ${ }^{19}$ The largest reducitons occur for the most disadvantaged groups. For example, referring to the results for annual earnings, the relative responsiveness of low skill nonwhite men fell by -0.81 . The relative responsiveness of family income

\footnotetext{
${ }^{19}$ Bartik (1995) finds no evidence of changes over time. Bartik's sample, however, ends in 1987 which is likely to be before the changes started taking place.
} 
fell by -1.08 for low education nonwhite men from an overall level of 2.09 . The table indicates that many of these reductions are statistically significantly different from zero. The reductions for low skilled nonwhite women were not as large. Overall, these results show that the 1992 recession was much more skill-group neutral than the 1982 recession.

Several sensitivity tests were performed for these models. In all cases, specific parameters changed somewhat but the qualitative results were the same. Changing the definition of race from white/nonhispanic and black/hispanic to white and black, led to larger racial differences. Hispanic men appear to be more like whites in that they have relatively high employment rates and relatively less cyclical variation. They also have relatively low education levels so they are a sizeable fraction of the low educated nonwhite group. Expanding the skill groups by considering four education groups led to larger differences between education levels. However, the precision of the estimates declined somewhat and many of the differences were not statistically significant. ${ }^{20}$

\section{Conclusion}

This paper uses data from the Current Population Survey covering the period 1975-1997 to examine how business cycles impact the employment, earnings, and income of low skill groups relative to high skill groups. The results consistently show that those with lower education levels, nonwhites, and low skilled nonwhite women, are more impacted by cycles than high skill white men. The analysis of family income shows that there is evidence that government transfers are effective at narrowing the differences in impacts across demographic groups.

\footnotetext{
${ }^{20}$ Other specification tests included (1) limiting the MSA sample to the largest 15-20 MSAs, (2) dropping "seam" years when the MSA boundaries change, and (3) dropping the 1995 and 1996 ADF years when the topcode on earnings increased significantly. The results were not sensitive to changing the MSA sample or dropping the seam years. Dropping the most recent ADF years did lead to modest increases in the relative responsiveness of the earnings and income of low skill groups. Looking back at Figure $2 \mathrm{~b}$, the earnings of high educated white men increased significantly with the increase in topcodes in 1995. Given that this was in a recovery, dropping those years leads to larger differences in the cyclical variation skill groups.
} 
The results also suggest that the 1992 recession and subsequent recovery had differential impacts compared to the 1982 recession and recovery. In particular, in the $1989-1996$ period, the sensitivity to cyclical variation of less skilled groups was still larger than high skill groups, but the differences narrowed. This may be in part due to the fact that the less skilled groups had somewhat low employment rates going in to the 1992 recession. It also may reflect differences in the industries that were affected in the 1992 versus 1982 recessions. Identifying the sources of this change is important and should be examined in future work. 


\section{References}

Acs, Gregory and Douglas Wissoker. 1991. "The Impact of Local Labor Markets on the Employment Patterns of Young Inner-City Males." Mimeo, Urban Institute.

Bartik, Timothy J. 1991. Who Benefits from State and Local Economic Development Policies? W.E. Upjohn Institute for Employment Research. Kalamazoo Michigan.

. 1993a "The Effects of Local Labor Markets on Individual Labor Market Outcomes for Different Demographic Groups and the Poor.” W.E. Upjohn Institute Working Paper 93-23.

. 1993b "Economic Development and Black Economic Success." Upjohn Institute Technical Report No. 93-001.

1994 "The Effects of Metropolitan Job Growth on the Size Distribution of Family Income.” Journal of Regional Science 34(4):483-501.

1996. "The Distributional Effects of Local Labor Demand and Industrial Mix: Estimates Using Individual Panel Data." Journal of Urban Economics 40(2):150-178.

Bils, Mark. 1985. "Real Wages over the Business Cycle: Evidence from Panel Data." Journal of Political Economy 93(4) pp. 666-689.

Blanchard, Olivier J. and Lawrence F. Katz. 1992. "Regional Evolutions." Brookings Papers on Economic Activity 1:1992.

Blank, Rebecca. 1989. "Disaggregating the Effect of the Business Cycle on the Distribution of Income." Economica 56:141-163.

Blank, Rebecca. 1990 "Why are Wages Cyclical in the 1970s?" Joumal of Labor Economics 8(1):16-47.

Blank, Rebecca. 1993. "Why Were Poverty Rates So High in the 1980s?" In Poverty and Prosperity in the Late Twentieth Century, ed. Dimitri Papadimitriou and Edward Wolff. New York: St. Martin's Press.

Blank, Rebecca and Alan Blinder. 1986. "Macroeconomics, Income Distribution, and Poverty." In Fighting Poverty: What Works and What Doesn't, ed. Sheldon Danziger and Daniel Weinberg. Cambridge, MA: Harvard University Press.

Blank, Rebecca and David Card. 1993. "Poverty, Income Distribution and Growth: Are They Still Related?" Brookings Papers on Economic Activity, 2:1993.

Blank, Rebecca, David Card, and Philip Robins. 1998. "Financial Incentives for Increasing Work and Income Among Low-Income Families." Paper prepared for the Joint Center for Poverty Research conference on "Labor Markets and Less Skilled Workers".

Blau, Francine. 1998. “Trends in the Well-Being of American Women, 1970-1995.” Journal of 
Economic Literature 36(1):112-165.

Bound, John and Richard Freeman. 1992. "What Went Wrong? The Erosion of Relative Earnings and Employment Among Young Black men in the 1980s" The Quarterly Journal of Economics, 107:201-232.

Bound, John and Harry Holzer. 1993. "Industrial Shifts, Skill Levels, and the Labor Market for White and Black Males". The Review of Economics and Statistics, August.

. 1995. "Structural Changes, Employment Outcomes, and Population Adjustments Among Whites and Blacks: 1980-1990." Institute for Research on Poverty Discussion Paper \#1057-95.

Cain, Glen and Ross Finnie. 1990. "The Black-White Difference in Youth Employment: Evidence from Demand Side Factors." Journal of Labor Economics 8:S364-95.

Card, David. 1995. “The Wage Curve: A Review.” Journal of Economic Literature 33:785-799.

Cutler, David and Lawrence Katz. 1991. "Macroeconomic Performance and the Disadvantaged." Brookings Papers on Economic Activity 2:1991.

Farber, Henry. 1997. "The Changing Face of Job Loss in the United States, 1981-1995.” Mimeo, Princeton University.

Freeman, Richard. 1982. "Economic Determinants of Geographic and Individual Variation in the Labor Market Position of Young Persons." In The Youth Labor Market Problem: Its Nature, Causes, and Consequences, ed. R Freeman and D. Wise. Chicago: University of Chicago Press.

1991a. "Labour Market Tightness and the Mismatch Between Demand and Supply of Less-Educated Young Men in the United States in the 1980s." In Mismatch and Labour Mobility, ed. P. Schioppa. Cambridge: Cambridge University Press.

. 1991b. "Employment and Earnings of Disadvantaged Young Men in a Labor Shortage Economy." In The Urban Underclass, ed. C. Jencks and Peterson. Washington DC: Brookings Institution Press.

Holzer, Harry J. 1991. "Employment, Unemployment, and Demand Shifts in Local Labor Markets." The Review of Economics and Statistics.

Karoly, Lynn. 1992. "The Trend in Inequality Among Families, Individuals and Workers in the United States." In Uneven Tides: Rising Inequality in America, ed. Sheldon Danziger and Peter Gottschalk. New York: The Russell Sage Foundation.

Katz, Lawrence and Kevin Murphy. 1992. "Changes in Relative Wages, 1963-1987: Supply and Demand Factors." The Quarterly Journal of Economics, 107:35-78.

Keane, Michael, Robert Moffitt and David Runkle. 1988. "Real Wages over the Business cycles: Estimating the Impact of Heterogeneity with Micro Data.” Journal of Political Economy 
$96: 1232-1266$.

Solon, Gary, Robert Barsky and Jonathan Parker. 1994. "Measuring the Cyclicality of Real Wages: How Important is Composition Bias?" Quarterly Journal of Economics 109(1):1-26. 

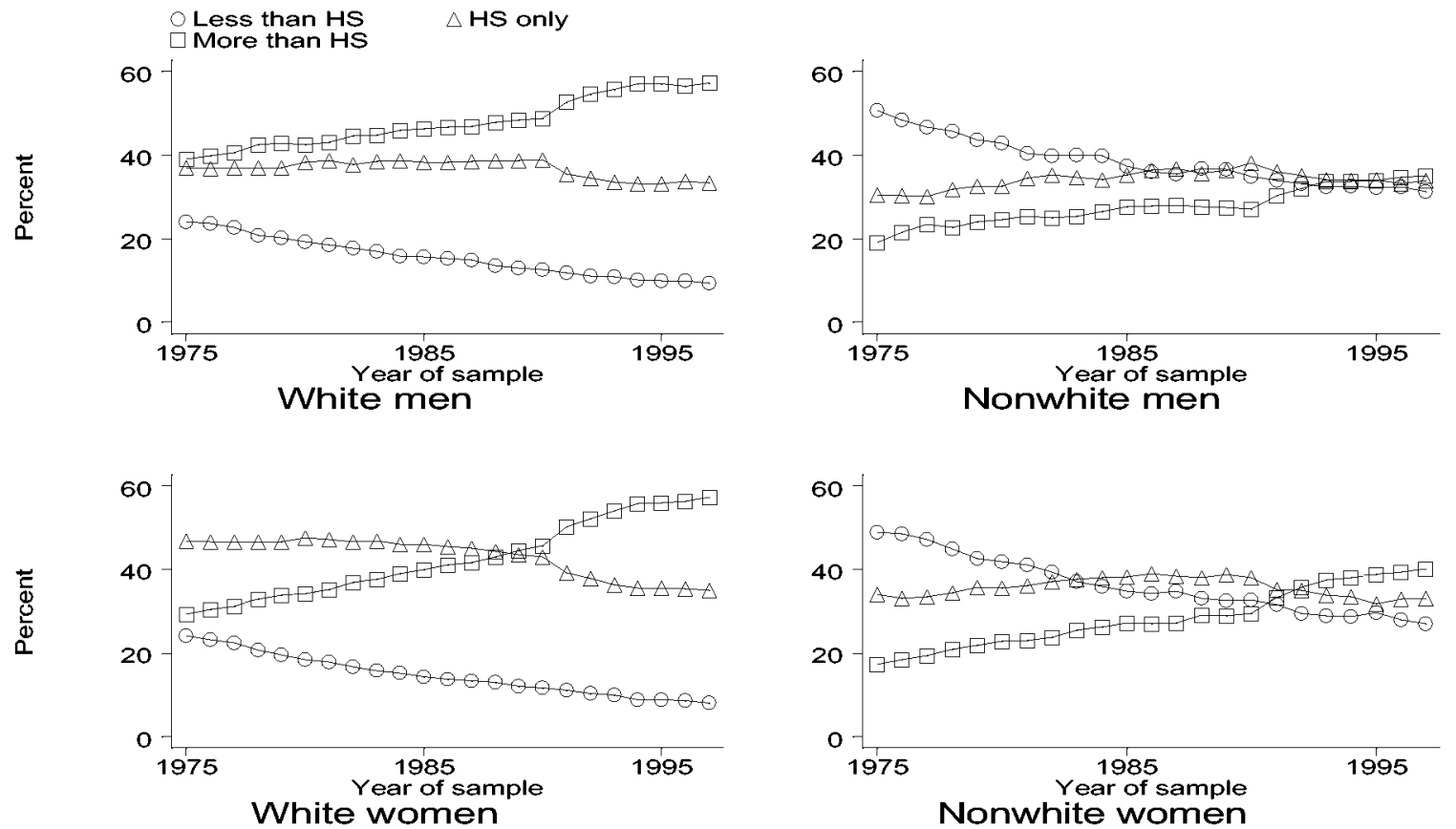
Annual demographic file, 1975-1997

Percent Distribution of Persons by Education, by Race and Sex

Figure 1 

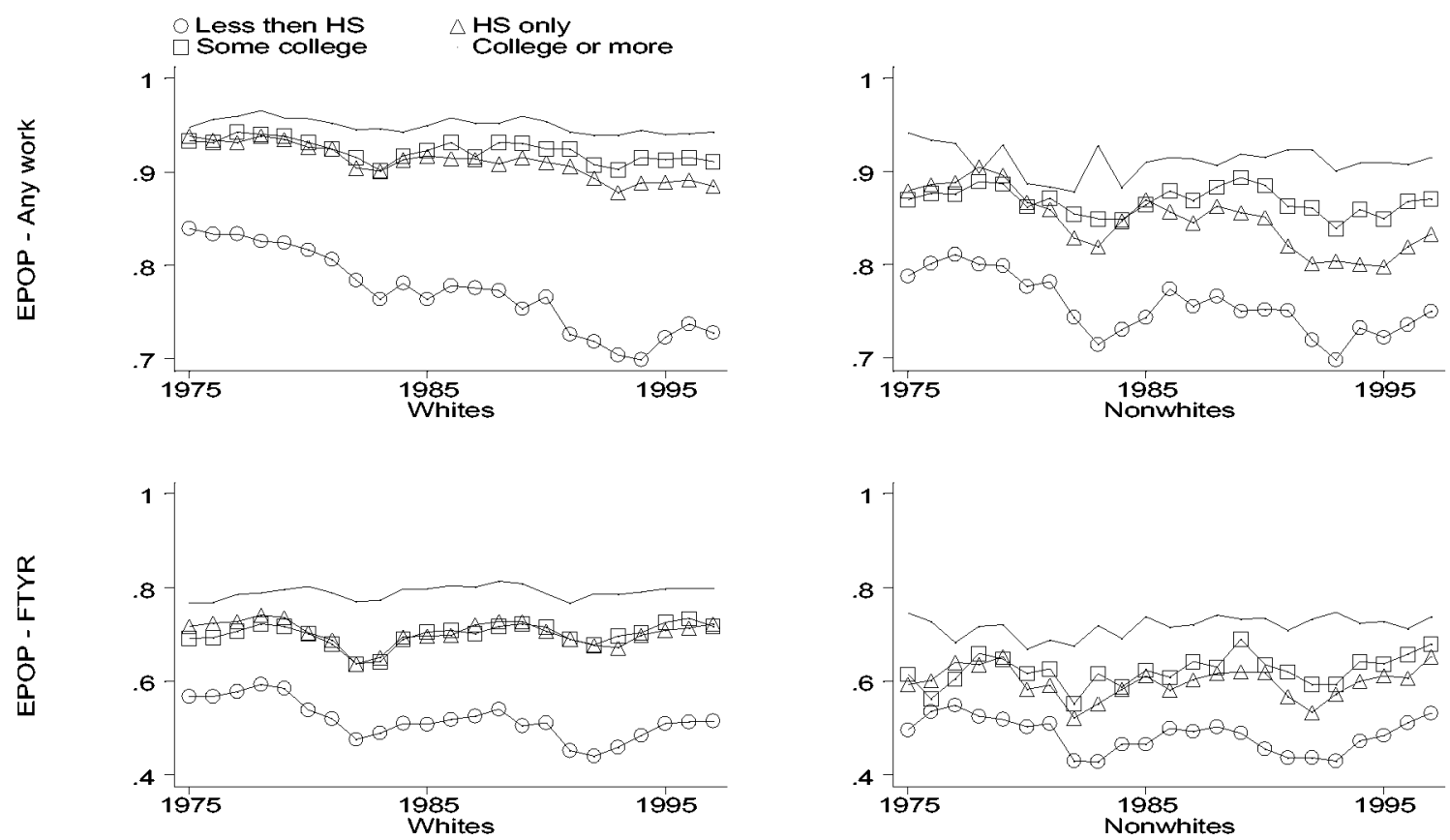

Annual Demographic File, 1975-1997

Annual Employment Outcomes, by Race and Education, Men

Figure 2a 

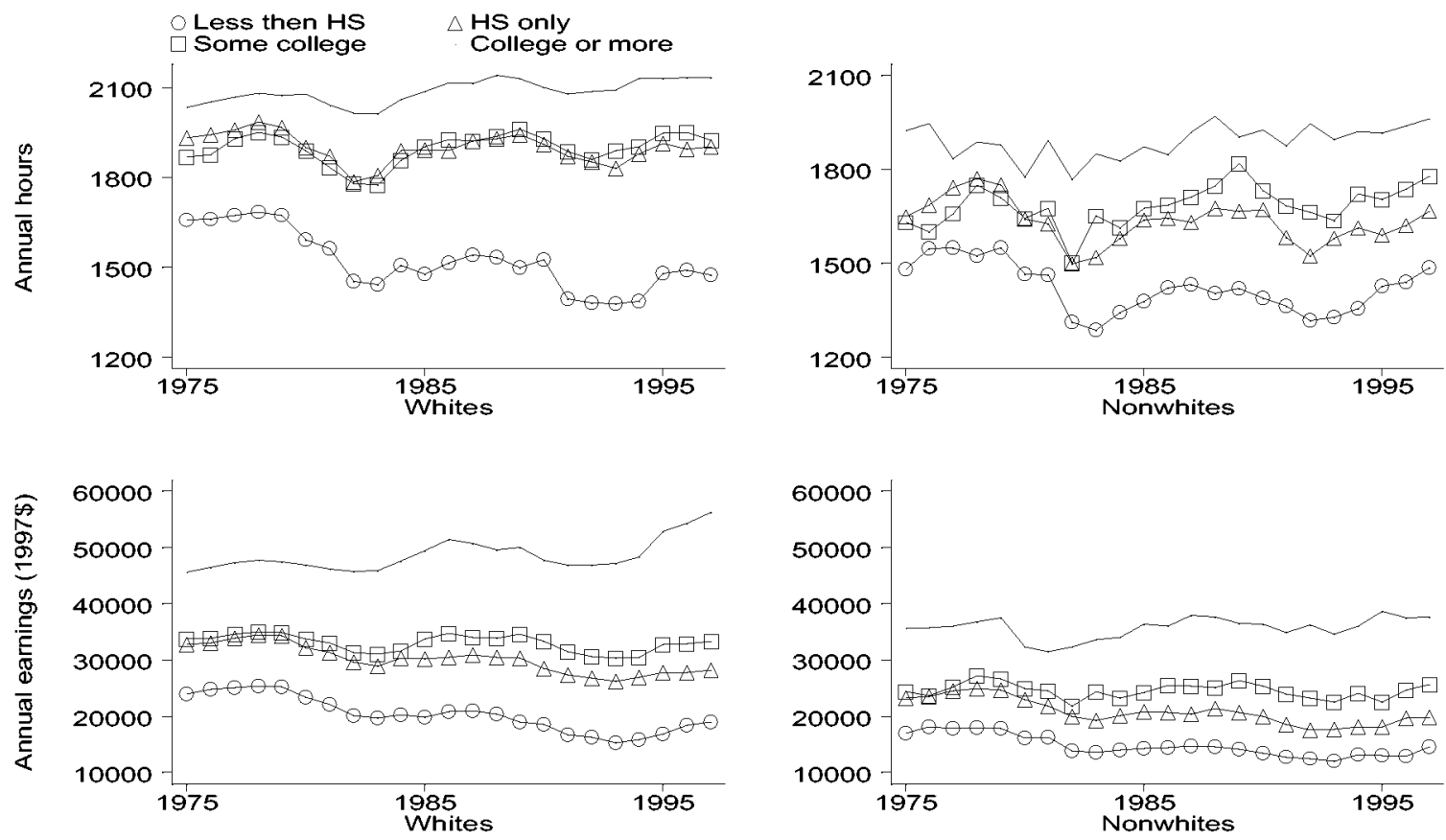

Annual Demographic File, 1975-1997

Annual Hours and Earnings, by Race and Education, Men

Figure 2b 

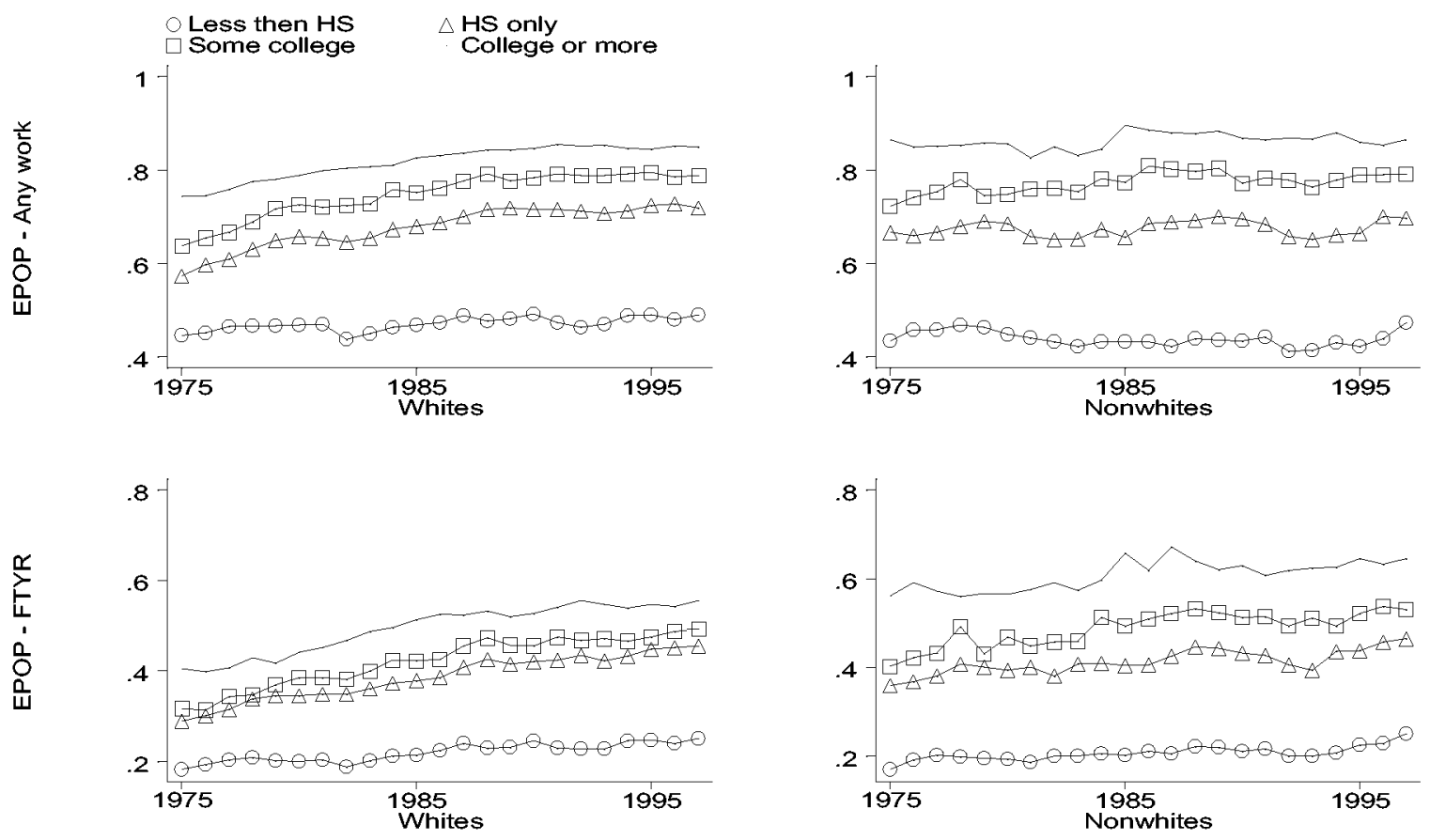

Annual Demographic File, 1975-1997

Annual Emp. Outcomes, by Race and Education, Women

Figure 3a 

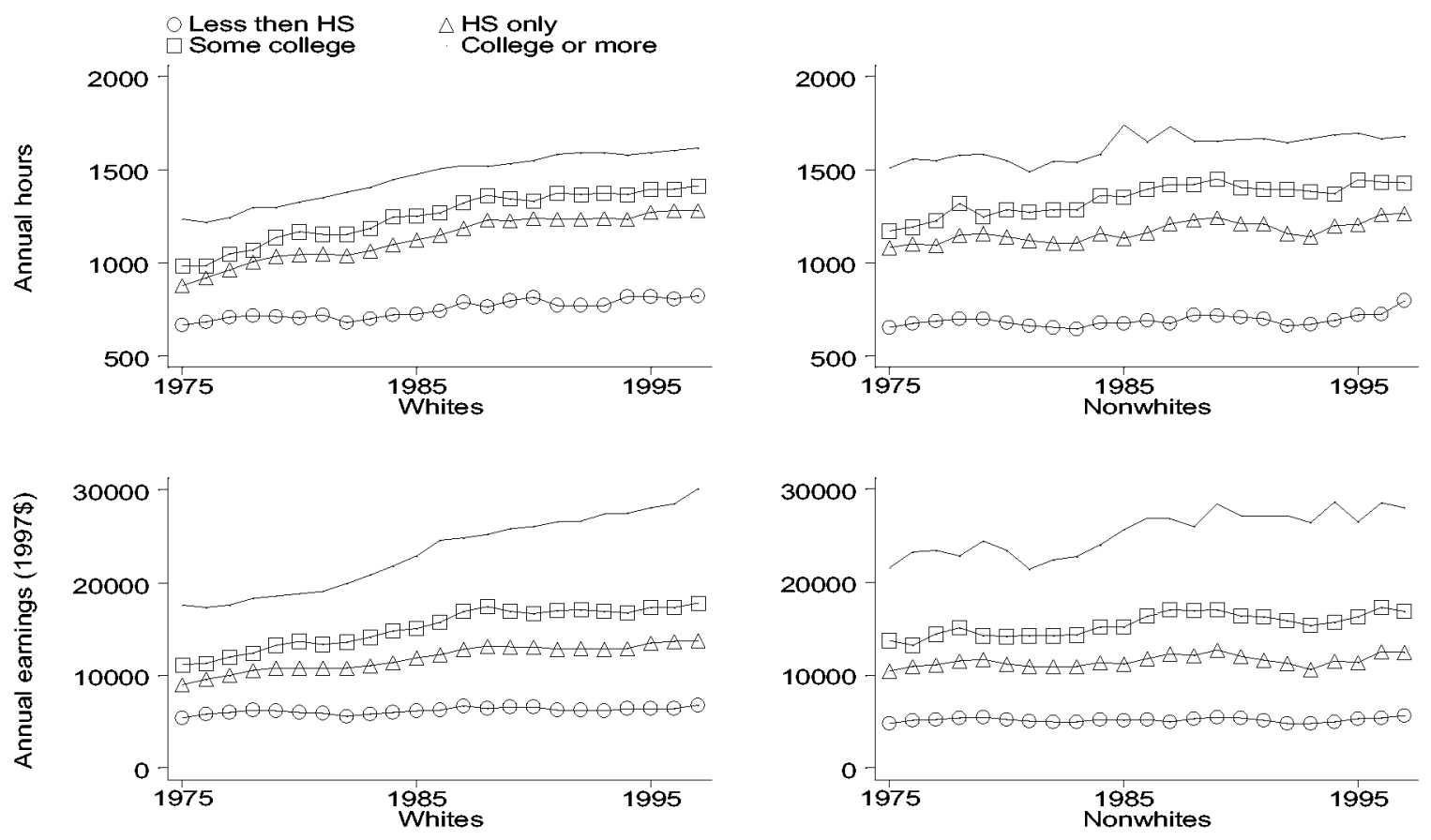

Annual Demographic File, 1975-1997

Annual Hours and Earnings, by Race and Education, Women

Figure 3b 

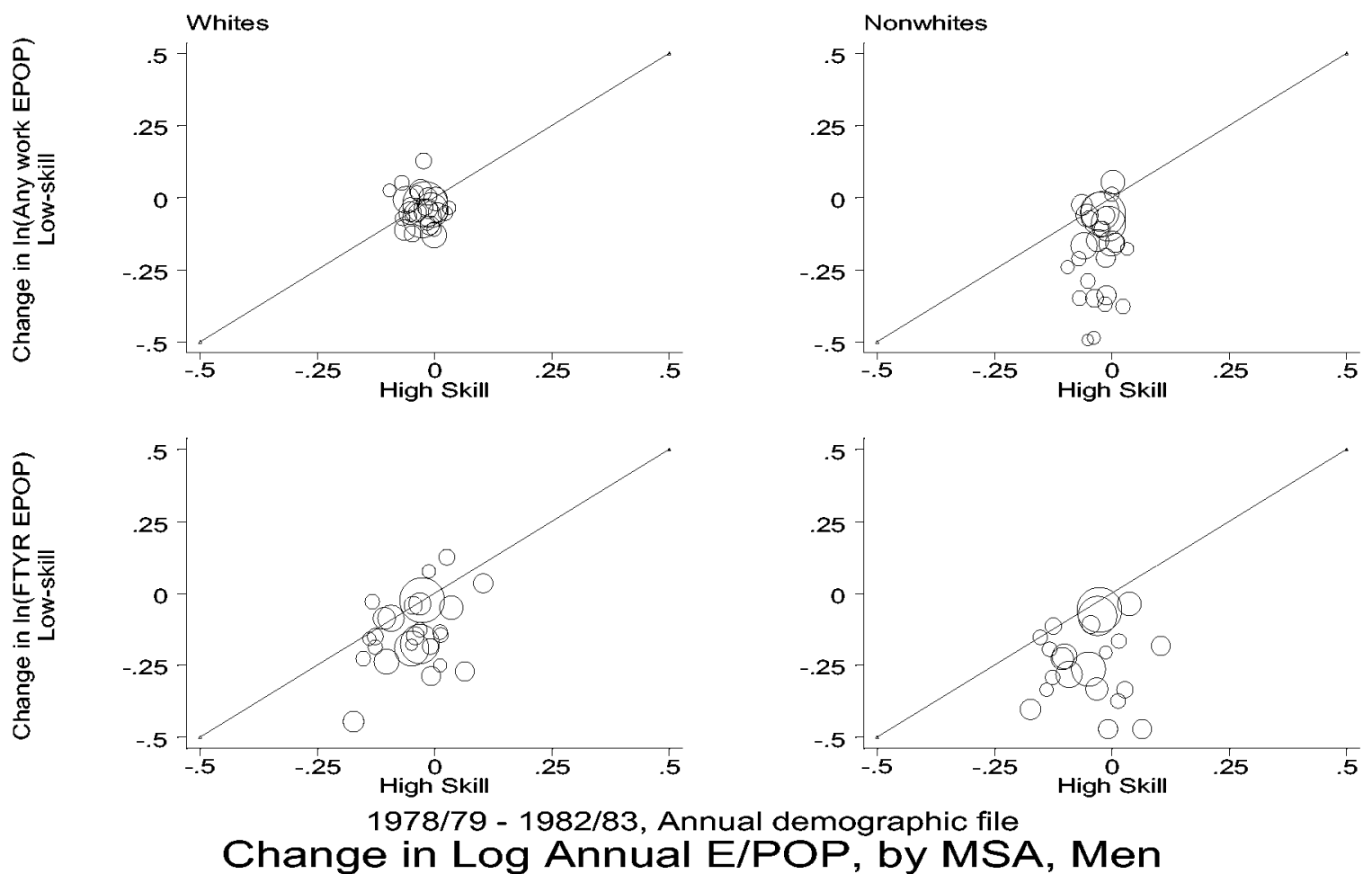
Change in Log Annual E/POP, by MSA, Men

\section{Figure 4}



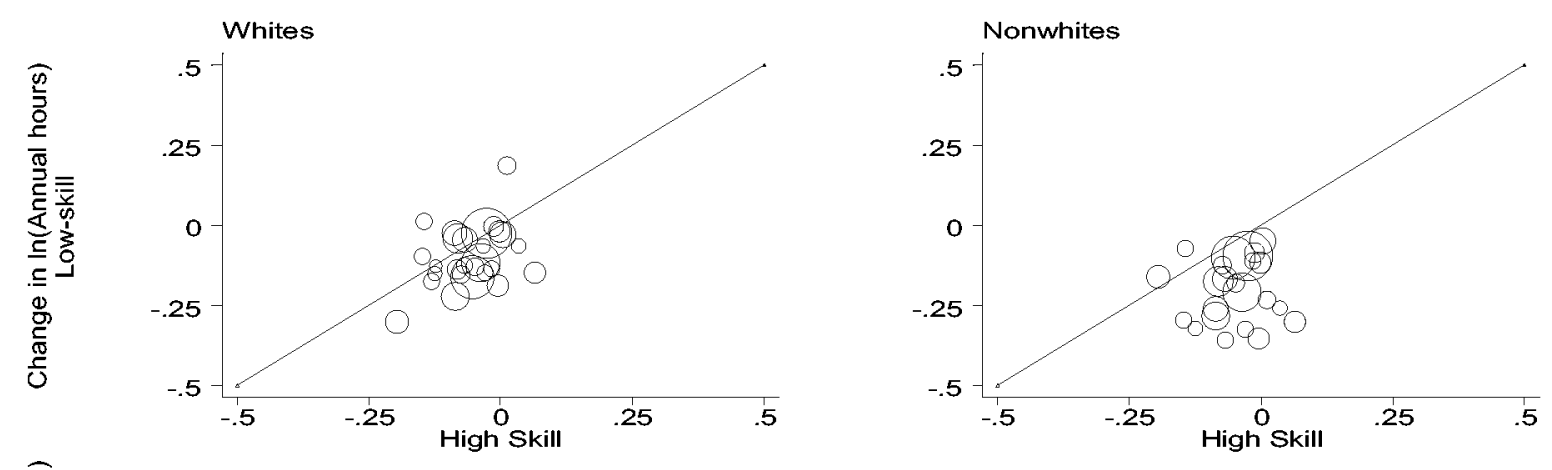

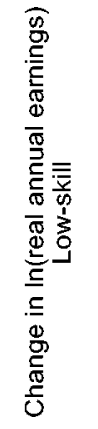
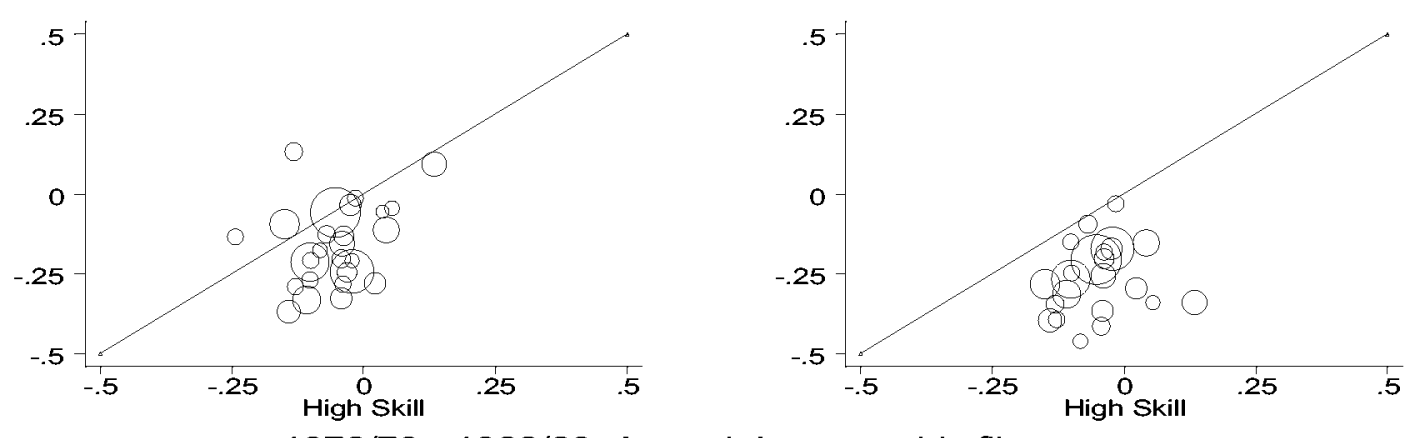

Change in Log Ann. Hours and Earnings, by MSA, Men

Figure 5 

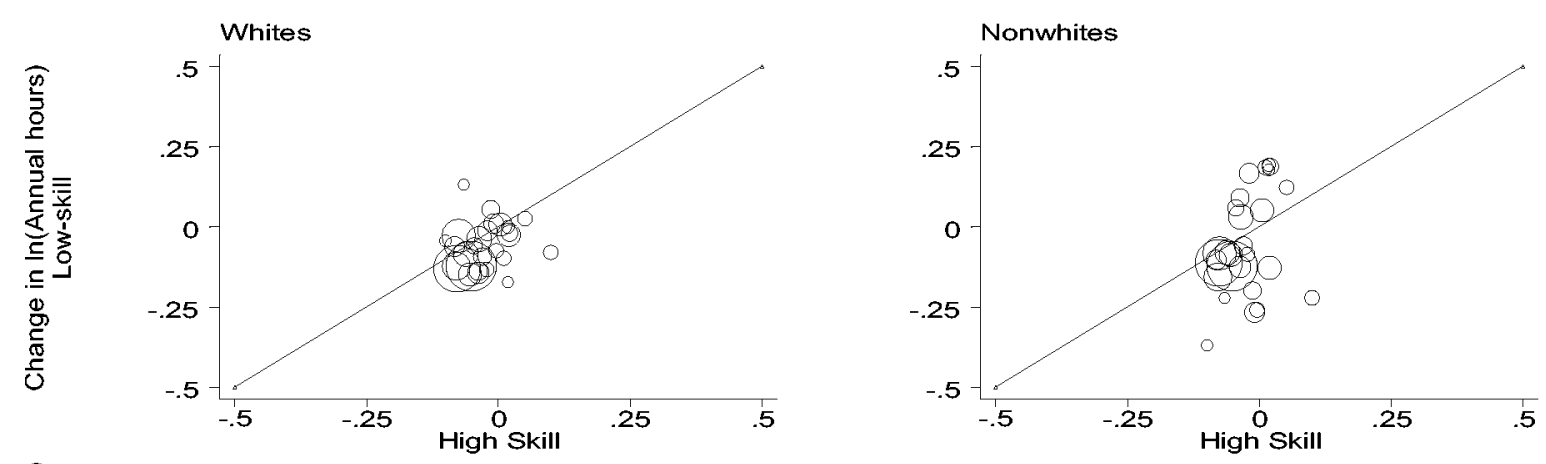

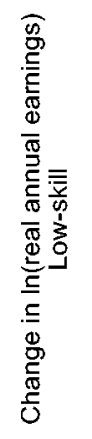
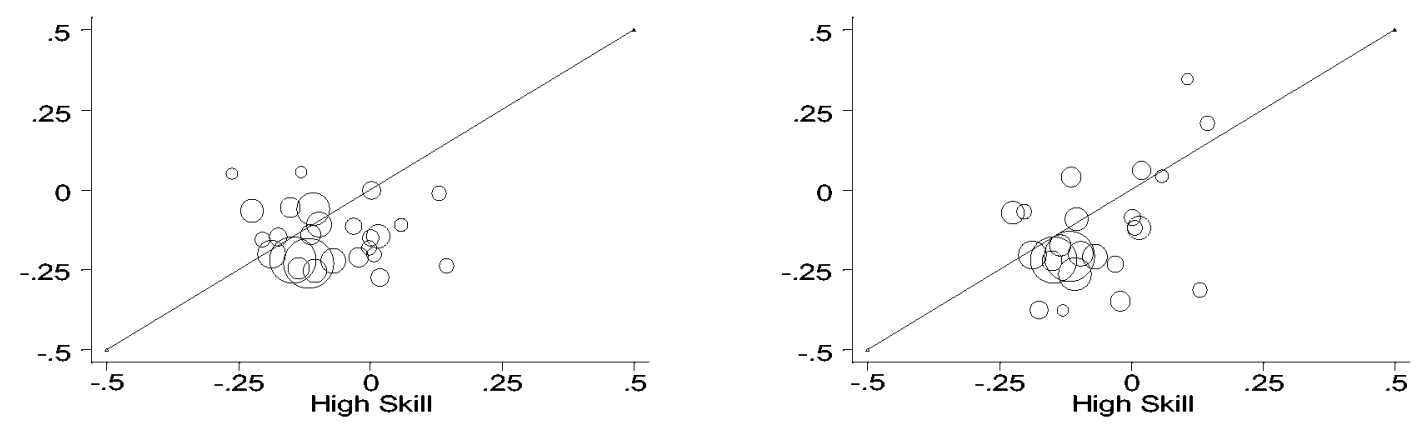

1988/89 - 1992/93, Annual demographic file

Change in Log Ann. Hours and Earnings, by MSA, Men

Figure 6 
Table 1

Change in the Log of Male Employment to Population Ratio in Selected MSAs, 1979-1982 and 1989-1992

\begin{tabular}{|c|c|c|c|}
\hline \multicolumn{4}{|c|}{ Change in the Log of Male $A n y$-work EPOP between 1979 and 1982} \\
\hline$\underline{\text { Large Reduction }}$ & & $\underline{\text { Small Reduction }}$ & \\
\hline Detroit & -0.14 & Denver & -0.05 \\
\hline Pittsburgh & -0.13 & Washington DC & -0.03 \\
\hline Columbus, $\mathrm{OH}$ & -0.12 & San Francisco & -0.03 \\
\hline Milwaukee & -0.11 & New York & -0.02 \\
\hline Cleveland & -0.10 & Boston & -0.01 \\
\hline \multicolumn{4}{|c|}{ Change in the Log of Male Any-work EPOP between 1989 and 1992} \\
\hline$\underline{\text { Large Reduction }}$ & & $\underline{\text { Small Reduction }}$ & \\
\hline New Orleans & -0.15 & Miami & 0.00 \\
\hline San Diego & -0.09 & Kansas City & 0.00 \\
\hline Boston & -0.08 & Detroit & 0.01 \\
\hline New York & -0.07 & Cleveland & 0.02 \\
\hline San Francisco & -0.07 & Houston & 0.02 \\
\hline
\end{tabular}

Notes: Author's tabulations of CPS Outgoing Rotation Group Data. EPOP is defined as the weighted number of men working last year over the weighted male population in the MSA. The sample includes all men who are between the ages of 22 and 62. We exclude those working without pay, the self employed, and those with weekly earnings less than $\$ 67$ in 1982 dollars. For more detail on sample selection, see text. 
Table 2

Regression Results Using CPS Outgoing Rotation Group Coefficients on MSA Shock

\begin{tabular}{|c|c|c|c|c|c|}
\hline & $\begin{array}{c}(1) \\
\text { Any-work } \\
\text { E/POP } \\
(\log )\end{array}$ & $\begin{array}{c}F T E / P O P \\
(\log )\end{array}$ & $\begin{array}{c}\text { (3) } \\
\text { Any-work } \\
\text { E/POP } \\
\text { (level) }\end{array}$ & $\begin{array}{c}\text { (4) } \\
\text { FT E/POP } \\
\text { (level) }\end{array}$ & $\begin{array}{c}\text { (5) } \\
\text { Mean } \\
\text { Weekly } \\
\text { Earnings } \\
\text { (log) }\end{array}$ \\
\hline \multicolumn{6}{|l|}{ Skill Group: } \\
\hline High educ $(>12)$ white men & 1 & 1 & 1 & 1 & 1 \\
\hline High educ $(>12)$ non-white men & $\begin{array}{c}1.28 \\
(0.47)\end{array}$ & $\begin{array}{c}1.73 \\
(0.51)\end{array}$ & $\begin{array}{c}1.30 \\
(0.28)\end{array}$ & $\begin{array}{c}1.34 \\
(0.25)\end{array}$ & $\begin{array}{c}1.46 \\
(0.24)\end{array}$ \\
\hline High ed ( $>12)$ white women & $\begin{array}{l}0.56 * \\
(0.19)\end{array}$ & $\begin{array}{c}0.90 \\
(0.23)\end{array}$ & $\begin{array}{l}0.57^{* *} \\
(0.11)\end{array}$ & $\begin{array}{l}0.52 * * \\
(0.10)\end{array}$ & $\begin{array}{c}0.85 \\
(0.11)\end{array}$ \\
\hline High ed (>12) non-white women & $\begin{array}{c}1.21 \\
(0.44)\end{array}$ & $\begin{array}{c}1.61 \\
(0.47)\end{array}$ & $\begin{array}{c}1.09 \\
(0.26)\end{array}$ & $\begin{array}{c}1.10 \\
(0.23)\end{array}$ & $\begin{array}{c}1.01 \\
(0.21)\end{array}$ \\
\hline Low ed $(\leq 12)$ white men & $\begin{array}{c}1.36 \\
(0.28)\end{array}$ & $\begin{array}{c}1.45 \\
(0.31)\end{array}$ & $\begin{array}{c}1.29 \\
(0.17)\end{array}$ & $\begin{array}{l}1.35 * \\
(0.16)\end{array}$ & $\begin{array}{c}1.22 \\
(0.14)\end{array}$ \\
\hline Low ed $(\leq 12)$ nonwhite men & $\begin{array}{l}3.88 * * \\
(0.69)\end{array}$ & $\begin{array}{l}3.51^{* *} \\
(0.66)\end{array}$ & $\begin{array}{l}2.95 * * \\
(0.35)\end{array}$ & $\begin{array}{l}2.77 \text { ** } \\
(0.30)\end{array}$ & $\begin{array}{l}1.99 * * \\
(0.22)\end{array}$ \\
\hline Low ed $(\leq 12)$ white women & $\begin{array}{c}1.53 \\
(0.29)\end{array}$ & $\begin{array}{l}2.38 * * \\
(0.44)\end{array}$ & $\begin{array}{c}0.82 \\
(0.13)\end{array}$ & $\begin{array}{l}0.63^{* *} \\
(0.11)\end{array}$ & $\begin{array}{c}0.94 \\
(0.12)\end{array}$ \\
\hline Low ed $(\leq 12)$ nonwhite women & $\begin{array}{l}5.42 * * \\
(0.91)\end{array}$ & $\begin{array}{l}4.49 * * \\
(0.81)\end{array}$ & $\begin{array}{l}1.44 * \\
(0.22)\end{array}$ & $\begin{array}{c}1.12 \\
(0.18)\end{array}$ & $\begin{array}{l}1.49 * * \\
(0.18)\end{array}$ \\
\hline $\mathrm{N}$ & 1680 & 1680 & 1680 & 1680 & 1680 \\
\hline $\mathrm{R}^{2}$ & 0.39 & 0.38 & 0.40 & 0.39 & 0.47 \\
\hline
\end{tabular}

Notes: Each column is a separate regression where the dependent variable is the change in the log or level of the labor market outcome evaluated at the mean for the cell defined by MSA, year, and skill group. The parameter estimates reported in the table are the coefficients on the MSA-time shock for each skill group. The regression also includes intercepts for each skill group capturing average growth rates in the labor market outcome for each skill group. The regression is estimated using nonlinear weighted least squares, using the cell's population as the weight. The sample is from the CPS ORG data and covers 1979-1993. The data are grouped into two year periods to increase cell sizes. All labor market outcome variables correspond to the week preceding the interview. For details on sample selection and variable construction, see the text. Standard errors are in parentheses. $\mathrm{A}^{* *}\left[{ }^{*}\right]$ indicates the parameter is significantly different from 1 at the $1 \%[5 \%]$ level. 
Table 3

Pooled Regression Results Using CPS Outgoing Rotation Group

Coefficients on MSA Shock

\begin{tabular}{|c|c|c|c|}
\hline & $\begin{array}{c}\text { Any-work E/POP } \\
\text { (level) }\end{array}$ & $\begin{array}{c}\text { FTE/POP } \\
\text { (level) }\end{array}$ & $\begin{array}{c}\text { (3) } \\
\text { Mean Weekly } \\
\text { Earnings } \\
\text { (log) }\end{array}$ \\
\hline \multicolumn{4}{|c|}{ Coefficients on MSA Shock, by Skill Group: } \\
\hline High educ $(>12)$, white men & 1 & $1.31(0.20)$ & $2.96(0.42)$ \\
\hline High educ ( $>12)$, non-white men & $1.63(0.34)$ & $1.88(0.38)$ & $4.36(0.80)$ \\
\hline High educ $(>12)$, white women & $0.60(0.14)$ & $0.72(0.15)$ & $2.47(0.39)$ \\
\hline High educ $(>12)$, non-white women & $1.26(0.30)$ & $1.11(0.32)$ & $3.18(0.68)$ \\
\hline Low educ $(\leq 12)$, white men & $1.37(0.21)$ & $1.64(0.24)$ & $3.79(0.52)$ \\
\hline Low educ $(\leq 12)$, nonwhite men & $2.92(0.39)$ & $3.22(0.43)$ & $6.34(0.85)$ \\
\hline Low educ $(\leq 12)$, white women & $0.80 \quad(0.15)$ & $0.82(0.16)$ & $2.82(0.41)$ \\
\hline Low educ $(\leq 12)$, nonwhite women & $1.52(0.25)$ & $1.53(0.26)$ & $4.56(0.66)$ \\
\hline \multicolumn{4}{|c|}{ Coefficients on MSA Shock Relative to Skill Group 1: } \\
\hline High educ $(>12)$, white men & 1 & 1 & 1 \\
\hline High educ ( $>12)$, non-white men & 1.63 & 1.44 & $1.47 *$ \\
\hline High educ $(>12)$, white women & $0.60 * *$ & $0.55 * *$ & 0.83 \\
\hline High educ $(>12)$, non-white women & 1.26 & 0.84 & 1.07 \\
\hline Low educ $(\leq 12)$, white men & 1.37 & 1.25 & $1.28 *$ \\
\hline Low educ $(\leq 12)$, nonwhite men & $2.92 * *$ & $2.46 * *$ & $2.14 * *$ \\
\hline Low educ $(\leq 12)$, white women & 0.80 & $0.63 * *$ & 0.95 \\
\hline Low educ $(\leq 12)$, nonwhite women & $1.52 *$ & 1.20 & $1.54 * *$ \\
\hline $\mathrm{N}$ & 1680 & 1680 & 1680 \\
\hline $\mathrm{R}^{2}$ & 0.33 & 0.33 & 0.46 \\
\hline
\end{tabular}

Notes: Each column presents estimates of an equation where the dependent variable is the change in the log or level of the labor market outcome evaluated at the mean for the cell defined by MSA, year, and skill group. The equations are estimated jointly with the MSA shocks common to each equation. The parameter estimates reported in the table are the coefficients on the MSAtime shock for each skill group. The regression also includes intercepts for each skill group capturing average growth rates in the labor market outcome for each skill group. The regression is estimated using nonlinear weighted least squares, using the cell's population as the weight. The sample is from the CPS ORG data and covers 1979-1993. The data are grouped into two year periods to increase cell sizes. All labor market outcome variables correspond to the week preceding the interview. For details on sample selection and variable construction, see the text. Standard errors are in parentheses. A** [*] indicates the parameter is significantly different from 1 at the $1 \%[5 \%]$ level. 
Table 4

Pooled Regression Results Using Individual Measures from CPS Annual Demographic File (ADF) Coefficients on MSA Shock

\begin{tabular}{|c|c|c|c|c|}
\hline & $\begin{array}{c}\text { FTYR E/POP } \\
\text { (level) }\end{array}$ & $\begin{array}{c}\text { Annual Hours } \\
\text { (log) }\end{array}$ & $\begin{array}{c}(3) \\
\text { Annual } \\
\text { Earnings } \\
\text { (log) }\end{array}$ & $\begin{array}{l}\text { Hourly Wage } \\
\text { (log) }\end{array}$ \\
\hline \multicolumn{5}{|c|}{ Coefficients on MSA Shock, by Skill Group: } \\
\hline High educ ( $>12)$, white men & 1 & $1.21 \quad(0.28)$ & $3.24(0.56)$ & $2.83(0.54)$ \\
\hline High educ $(>12)$, non-white men & $2.26(0.50)$ & $2.76(0.67)$ & $5.03(1.03)$ & $2.70(0.94)$ \\
\hline High educ $(>12)$, white women & $0.02(0.26)$ & $0.11 \quad(0.21)$ & $1.10(0.33)$ & $1.02(0.37)$ \\
\hline High educ $(>12)$, non-white women & $0.96(0.36)$ & $1.38 \quad(0.51)$ & $2.52(0.74)$ & $0.77 \quad(0.76)$ \\
\hline Low educ $(\leq 12)$, white men & $1.38(0.26)$ & $1.60(0.33)$ & $3.38 \quad(0.59)$ & $2.06 \quad(0.49)$ \\
\hline Low educ $(\leq 12)$, nonwhite men & $2.82(0.49)$ & $3.97(0.70)$ & $6.15(1.05)$ & $2.10 \quad(0.69)$ \\
\hline Low educ $(\leq 12)$, white women & $0.58 \quad(0.17)$ & $1.48(0.30)$ & $2.86(0.51)$ & $1.88(0.44)$ \\
\hline Low educ $(\leq 12)$, nonwhite women & $2.04(0.39)$ & $4.69(0.78)$ & $7.66(1.23)$ & $4.01 \quad(0.82)$ \\
\hline \multicolumn{5}{|c|}{ Coefficients on MSA Shock Relative to Skill Group 1: } \\
\hline High educ ( $>12)$, white men & 1 & 1 & 1 & 1 \\
\hline High educ ( $>12)$, non-white men & $2.26 * *$ & $2.28 *$ & $1.55 *$ & 0.95 \\
\hline High educ $(>12)$, white women & $0.02 * *$ & $0.09 * *$ & $0.34 * *$ & $0.36 * *$ \\
\hline High educ $(>12)$, non-white women & 0.96 & 1.14 & 0.78 & $0.27 * *$ \\
\hline Low educ $(\leq 12)$, white men & 1.38 & 1.32 & 1.04 & 0.72 \\
\hline Low educ $(\leq 12)$, nonwhite men & $2.82 * *$ & $3.28 * *$ & $1.90 * *$ & 0.74 \\
\hline Low educ $(\leq 12)$, white women & $0.58 * *$ & 1.22 & 0.88 & 0.66 \\
\hline Low educ $(\leq 12)$, nonwhite women & $2.04 * *$ & $3.88 * *$ & $2.36 * *$ & 1.42 \\
\hline $\mathrm{N}$ & 2160 & 2160 & 2160 & 2160 \\
\hline $\mathrm{R}^{2}$ & 0.16 & 0.17 & 0.29 & 0.09 \\
\hline
\end{tabular}

Notes: Each column presents estimates of an equation where the dependent variable is the change in the log or level of the labor market outcome evaluated at the mean for the cell defined by MSA, year, and skill group. The equations are estimated jointly with the MSA shocks common to each equation. The parameter estimates reported in the table are the coefficients on the MSAtime shock for each skill group. The regression also includes intercepts for each skill group capturing average growth rates in the labor market outcome for each skill group. The regression is estimated using nonlinear weighted least squares, using the cell's population as the weight. The sample is from the CPS ADF and covers 1975-1996. The data are grouped into two year periods to increase cell sizes. All labor market outcome variables correspond to the week preceding the interview. For details on sample selection and variable construction, see the text. Standard errors are in parentheses. A** [*] indicates the parameter is significantly different from 1 at the $1 \%[5 \%]$ level. 
Table 5

Pooled Regression Results Using Family Measures from CPS Annual Demographic File (ADF) Coefficients on MSA Shock

\begin{tabular}{|c|c|c|c|c|c|c|}
\hline & $\begin{array}{c}\text { Own } \\
\text { Earnings } \\
\text { (log) }\end{array}$ & $\begin{array}{c}\text { Head's } \\
\text { Earnings } \\
\text { (log) } \\
\end{array}$ & $\begin{array}{l}\text { Spouse's } \\
\text { Earnings } \\
\text { (log) }\end{array}$ & $\begin{array}{c}\text { (4) } \\
\text { Other } \\
\text { Family } \\
\text { Income } \\
\text { (log) } \\
\end{array}$ & $\begin{array}{c}\text { (5) } \\
\text { Total } \\
\text { Family } \\
\text { Earnings } \\
(\log ) \\
\end{array}$ & $\begin{array}{c}(6) \\
\\
\text { Total } \\
\text { Family } \\
\text { Income } \\
\text { (log) } \\
\end{array}$ \\
\hline \multicolumn{7}{|c|}{ Coefficients on MSA Shock, by Skill Group: } \\
\hline High ed white men & 1 & $0.94(0.14)$ & $0.54(0.19)$ & $1.00(0.23)$ & $0.81(0.12)$ & $0.81(0.11)$ \\
\hline High ed non-white men & $1.35(0.28)$ & $1.26(0.28)$ & $1.77(0.49)$ & $0.59(0.53)$ & $1.32(0.24)$ & $1.17(0.22)$ \\
\hline High ed white women & $0.34(0.10)$ & $0.86(0.13)$ & $0.23(0.18)$ & $1.23(0.24)$ & $0.72(0.11)$ & $0.75(0.10)$ \\
\hline High ed non-white women & $0.84(0.24)$ & $0.97(0.24)$ & $1.85(0.45)$ & $1.44(0.49)$ & $1.33(0.23)$ & $1.25(0.21)$ \\
\hline Low ed white men & $0.94(0.15)$ & $0.92(0.14)$ & $0.92(0.22)$ & $0.57(0.24)$ & $0.92(0.13)$ & $0.82(0.12)$ \\
\hline Low ed nonwhite men & $1.50(0.23)$ & $1.35(0.22)$ & $2.51(0.41)$ & $1.36(0.40)$ & $1.74(0.23)$ & $1.48(0.20)$ \\
\hline Low ed white women & $0.83(0.13)$ & $0.87(0.13)$ & $1.22(0.22)$ & $0.87(0.23)$ & $0.98(0.13)$ & $0.91(0.12)$ \\
\hline Low ed nonwhite women & $2.18(0.27)$ & $1.88(0.25)$ & $3.91(0.49)$ & $1.50(0.38)$ & $2.49(0.28)$ & $1.99(0.22)$ \\
\hline \multicolumn{7}{|c|}{ Coefficients on MSA Shock Relative to Skill Group 1: } \\
\hline High ed white men & 1 & 1 & 1 & 1 & 1 & 1 \\
\hline High ed non-white men & 1.35 & 1.34 & $3.28 *$ & 0.59 & $1.63 *$ & 1.44 \\
\hline High ed white women & $0.34 * *$ & 0.91 & 0.43 & 1.23 & 0.88 & 0.93 \\
\hline High ed non-white women & 0.84 & 1.03 & $3.42 * *$ & 1.44 & $1.64 *$ & 1.54 \\
\hline Low ed white men & 0.94 & 0.98 & 1.70 & 0.57 & 1.14 & 1.01 \\
\hline Low ed nonwhite men & $1.50 * *$ & $1.44 *$ & $4.64 * *$ & 1.36 & $2.15 * *$ & $1.83^{* *}$ \\
\hline Low ed white women & 0.83 & 0.93 & $2.26 * *$ & 0.87 & 1.21 & 1.12 \\
\hline Low ed nonwhite women & $2.18 * *$ & $2.00 * *$ & $7.24 * *$ & 1.50 & $3.07 * *$ & $2.46 * *$ \\
\hline $\mathrm{N}$ & 2160 & 2160 & 2160 & 2160 & 2160 & 2160 \\
\hline $\mathrm{R}^{2}$ & 0.22 & 0.31 & 0.31 & 0.19 & 0.13 & 0.03 \\
\hline
\end{tabular}

Notes: Each column presents estimates of an equation where the dependent variable is the change in the log of the labor market outcome evaluated at the mean for the cell defined by MSA, year, and skill group. The equations are estimated jointly with the MSA shocks common to each equation. The parameter estimates reported in the table are the coefficients on the MSA-time shock for each skill group. The regression also includes intercepts for each skill group capturing average growth rates in the labor market outcome for each skill group. The regression is estimated using nonlinear weighted least squares, using the cell's population as the weight. The sample is from the CPS ADF and covers 1975-1996. The data are grouped into two year periods to increase cell sizes. All labor market outcome variables correspond to the week preceding the interview. For details on sample selection and variable construction, see the text. Standard errors are in parentheses. $\mathrm{A}^{* *}\left[{ }^{*}\right]$ indicates the parameter is significantly different from 1 at the $1 \%[5 \%]$ level. 
Table 6

Means of Selected Characteristics by Skill Group, 1998 CPS Annual Demographic File (ADF)

\begin{tabular}{|c|c|c|c|c|c|c|c|c|}
\hline & \multicolumn{4}{|c|}{ High education $(>12)$} & \multicolumn{4}{|c|}{ Low education $(\leq 12)$} \\
\hline & \multicolumn{2}{|c|}{ Men } & \multicolumn{2}{|c|}{ Women } & \multicolumn{2}{|c|}{ Men } & \multicolumn{2}{|c|}{ Women } \\
\hline & White & Nonwhite & White & Nonwhite & White & Nonwhite & White & Nonwhite \\
\hline Age & 43.7 & 38.7 & 43.3 & 37.9 & 43.3 & 37.3 & 47.9 & 40.7 \\
\hline Head Earnings / Family Income (\%) & $66 \%$ & $63 \%$ & $60 \%$ & $60 \%$ & $59 \%$ & $59 \%$ & $54 \%$ & $54 \%$ \\
\hline Spouse Earnings / Family Income (\%) & $17 \%$ & $17 \%$ & $19 \%$ & $17 \%$ & $17 \%$ & $14 \%$ & $16 \%$ & $11 \%$ \\
\hline Welfare Income / Family Income (\%) & $0 \%$ & $0 \%$ & $0 \%$ & $2 \%$ & $0 \%$ & $2 \%$ & $2 \%$ & $7 \%$ \\
\hline Other Transfers / Family Income (\%) & $7 \%$ & $9 \%$ & $9 \%$ & $11 \%$ & $13 \%$ & $11 \%$ & $16 \%$ & $15 \%$ \\
\hline Any Work E/POP & 0.93 & 0.89 & 0.82 & 0.82 & 0.86 & 0.80 & 0.67 & 0.58 \\
\hline FTYR E/POP & 0.77 & 0.82 & 0.53 & 0.58 & 0.68 & 0.61 & 0.42 & 0.37 \\
\hline Union $(\%){ }^{1 /}$ & $42 \%$ & $30 \%$ & $40 \%$ & $35 \%$ & $38 \%$ & $27 \%$ & $40 \%$ & $30 \%$ \\
\hline \multicolumn{9}{|l|}{ Industrial Composition: ${ }^{1 /}$} \\
\hline Construction (\%) & $6.1 \%$ & $5.2 \%$ & $1.2 \%$ & $0.6 \%$ & $15.2 \%$ & $12.9 \%$ & $1.3 \%$ & $0.8 \%$ \\
\hline Manufacturing (\%) & $19.0 \%$ & $16.4 \%$ & $7.7 \%$ & $7.3 \%$ & $23.2 \%$ & $22.2 \%$ & $13.2 \%$ & $18.2 \%$ \\
\hline Retail Trade (\%) & $12.6 \%$ & $13.6 \%$ & $13.7 \%$ & $14.1 \%$ & $19.6 \%$ & $20.6 \%$ & $28.9 \%$ & $22.5 \%$ \\
\hline FIRE $(\%)$ & $6.7 \%$ & $5.3 \%$ & $8.8 \%$ & $9.5 \%$ & $2.3 \%$ & $2.4 \%$ & $7.8 \%$ & $4.9 \%$ \\
\hline Public Administration. (\%) & $7.3 \%$ & $9.7 \%$ & $5.1 \%$ & $7.3 \%$ & $2.9 \%$ & $2.0 \%$ & $3.4 \%$ & $3.2 \%$ \\
\hline \multicolumn{9}{|l|}{ Occupational Composition: ${ }^{1 /}$} \\
\hline$\%$ Managerial/Professional & $43.8 \%$ & $30.6 \%$ & $46.7 \%$ & $35.8 \%$ & $7.8 \%$ & $3.9 \%$ & $11.5 \%$ & $6.5 \%$ \\
\hline$\%$ Technical/Sales/Administrative & $23.5 \%$ & $24.2 \%$ & 38.7 & $44.5 \%$ & $15.6 \%$ & $11.9 \%$ & $48.0 \%$ & $34.2 \%$ \\
\hline$\%$ Service Occupations & $22.2 \%$ & $28.0 \%$ & $12.0 \%$ & $15.1 \%$ & $45.4 \%$ & $48.5 \%$ & $29.1 \%$ & $40.1 \%$ \\
\hline$\%$ Operators/Laborers & $10.4 \%$ & $17.2 \%$ & $2.7 \%$ & $4.6 \%$ & $31.3 \%$ & $35.6 \%$ & $11.5 \%$ & $19.3 \%$ \\
\hline Number of Observations & 15207 & 2937 & 17398 & 4020 & 15855 & 7378 & 19048 & 8452 \\
\hline
\end{tabular}

1/ Means apply to the sample of persons working as of the survey week. 
Table 7

Pooled Regression Results Using Family Measures from CPS Annual Demographic File (ADF) Allowing For Changes in Parameters Over Time

\begin{tabular}{|c|c|c|c|}
\hline & $\begin{array}{c}\text { (1) } \\
\text { Own } \\
\text { Annual Earnings } \\
\text { (log) }\end{array}$ & $\begin{array}{c}\text { (2) } \\
\text { Total } \\
\text { Family Earnings } \\
\text { (log) }\end{array}$ & $\begin{array}{c}\text { (3) } \\
\text { Total } \\
\text { Family Income } \\
(\log )\end{array}$ \\
\hline \multicolumn{4}{|c|}{ Coefficients on MSA Shock, by Skill Group: All Years } \\
\hline High educ $(>12)$, white men & 1 & $0.80(0.18)$ & $0.76(0.16)$ \\
\hline High educ $(>12)$, non-white men & $2.02(0.51) * *$ & $1.90(0.45) * *$ & $1.70(0.40) * *$ \\
\hline High educ $(>12)$, white women & $0.85 \quad(0.20)$ & $0.77(0.18)$ & $0.76 \quad(0.17)$ \\
\hline High educ $(>12)$, non-white women & $1.61 \quad(0.44)$ & $1.69(0.40) *$ & $1.67(0.38) * *$ \\
\hline Low educ $(\leq 12)$, white men & $1.25(0.25)$ & $1.10(0.21)$ & $0.93(0.18)$ \\
\hline Low educ $(\leq 12)$, nonwhite men & $2.14(0.42) * *$ & $2.38(0.42) * *$ & $1.97(0.36) * *$ \\
\hline Low educ $(\leq 12)$, white women & $1.06(0.21)$ & $1.12(0.21)$ & $0.94 \quad(0.18)$ \\
\hline Low educ $(\leq 12)$, nonwhite women & $2.39(0.43) * *$ & $2.60(0.44) * *$ & $2.09(0.36) * *$ \\
\hline \multicolumn{4}{|c|}{ Coefficients on MSA Shock by Skill Group: Post 1988} \\
\hline High educ $(>12)$, white men 0 & 0 & $\begin{aligned}-0.03 & (0.21) \\
0.00 & \end{aligned}$ & $\begin{array}{rr}-0.04 & (0.19) \\
0.00 & \end{array}$ \\
\hline High educ $(>12)$, non-white men & $-0.96(0.56)$ & $\begin{array}{l}-1.15(0.48) * * \\
-1.12\end{array}$ & $\begin{array}{l}-1.09(0.43) * * \\
-1.05\end{array}$ \\
\hline High educ $(>12)$, white women & $-0.69(0.22) * *$ & $\begin{array}{ll}-0.09 & (0.20) \\
-0.06 & \end{array}$ & $\begin{array}{ll}-0.12 & (0.19) \\
-0.08 & \end{array}$ \\
\hline High educ $(>12)$, non-white women & $-1.28(0.48) * *$ & $\begin{array}{ll}-0.83 & (0.44) \\
-0.80 & \end{array}$ & $\begin{array}{l}-0.92(0.40) * \\
-0.88\end{array}$ \\
\hline Low educ $(\leq 12)$, white men & $-0.30(0.29)$ & $\begin{array}{ll}-0.28 & (0.25) \\
-0.24 & \end{array}$ & $\begin{array}{ll}-0.23 & (0.21) \\
-0.19 & \end{array}$ \\
\hline Low educ $(\leq 12)$, nonwhite men & $-0.81(0.46)$ & $\begin{array}{l}-1.25(0.45) * * \\
-1.22\end{array}$ & $\begin{array}{l}-1.12(0.38) * * \\
-1.08\end{array}$ \\
\hline Low educ ( $\leq 12)$, white women & $-0.49(0.24)$ & $\begin{array}{ll}-0.24 & (0.24) \\
-0.21 & \end{array}$ & $\begin{array}{ll}-0.13 & (0.21) \\
-0.09 & \end{array}$ \\
\hline Low educ $(\leq 12)$, nonwhite women & $-0.58 \quad(0.49)$ & $\begin{array}{ll}-0.48 & (0.50) \\
-0.44 & \end{array}$ & $\begin{array}{l}-0.46 \quad(0.41) \\
-0.42\end{array}$ \\
\hline $\mathrm{N}$ & 2160 & 2160 & 2160 \\
\hline $\mathrm{R}^{2}$ & 0.30 & 0.37 & 0.34 \\
\hline
\end{tabular}

Notes: Each column presents estimates of an equation where the dependent variable is the change in the log of the labor market outcome evaluated at the mean for the cell defined by MSA, year, and skill group. The equations are estimated jointly with the MSA shocks common to each equation. This specification allows the effects of MSA shocks to differ over the period. The top panel presents estimates corresponding to the full period and the bottom presents estimates for the post 1988 period. The numbers in italics in the bottom panel represent the changes in the skill group coefficient in the post- 88 period relative to the change for skill group 1. Standard errors are in parentheses. In the top panel, a ** [*] indicates the parameter is significantly different from 1 at the $1 \%[5 \%]$ level. In the bottom panel, $a^{* *}\left[{ }^{*}\right]$ indicates that the parameter is significantly different from 0 at the $1 \%[5 \%]$ level. 